\title{
Did Late Cretaceous cooling trigger the Campanian-Maastrichtian Boundary Event?
}

\author{
Christian Linnert ${ }^{1,2 *}$, Stuart A. Robinson ${ }^{3}$, Jackie A. Lees ${ }^{1}$, \\ Irene Pérez-Rodríguez ${ }^{4}$, Hugh C. Jenkyns ${ }^{3}$, Maria Rose Petrizzo ${ }^{5}$, \\ José A. Arz ${ }^{4}$, Paul R. Bown ${ }^{1}$, and Francesca Falzoni ${ }^{5}$
}

With 6 figures

\begin{abstract}
The Campanian-Maastrichtian (83-66 Ma) was a period of global climate cooling, featuring significant negative carbon-isotope $\left(\delta^{13} \mathrm{C}\right)$ anomalies, such as the Late Campanian Event (LCE) and the Campanian-Maastrichtian Boundary Event (CMBE). A variety of factors, including changes in temperature, oceanic circulation and gateway opening, have been invoked to explain these $\delta^{13} \mathrm{C}$ perturbations, but no precise mechanism has yet been well constrained. In order to improve our understanding of these events, we measured stable carbon and oxygen isotopes of hemipelagic sediments from the Shuqualak-Evans cored borehole (Mississippi, USA) and compared the data with previously published sea-surface temperature (SST) estimates from the same core. We found that the CMBE can be recognised, unambiguously, in the ShuqualakEvans core, and that it is associated with an interval of cooler SSTs suggesting a possible mechanistic link between palaeotemperature change and this event. Determining the precise position of the LCE in the Shuqualak-Evans core is more problematic, but it may also be associated with cooler SSTs. Our combined records of carbon cycling and SSTs compare well with other studies and provide evidence that cooling during the CMBE (and possibly LCE) was global in nature and affected surface waters, in addition to the deep-ocean. We suggest that short-term cooling drove intensification of high-latitude deep-water formation, which in turn led to changes in the ratio of carbonate to organic carbon burial that led to a negative $\delta^{13} \mathrm{C}$ excursion. Critically, the absence of warming during these intervals implies that the Late Cretaceous events must not have been associated with an appreciable increase in atmospheric $p \mathrm{CO}_{2}$, and was likely associated with decreased $p \mathrm{CO}_{2}$.
\end{abstract}

Key words. Latest Cretaceous cooling, carbon isotope excursions, Late Campanian Event, CampanianMaastrichtian Boundary Event

\footnotetext{
Authors' addresses:

1 Department of Earth Sciences, University College London, Gower Street, London, WC1E 6BT, UK.

2 Ruhr-Universität Bochum, Fakultät für Geowissenschaften, Institut für Geologie, Mineralogie und Geophysik, Universitätsstr. 150, 44780 Bochum, Germany.

3 Department of Earth Sciences, University of Oxford, South Parks Road, Oxford, OX1 3AN, UK.

4 Departamento de Ciencias de la Tierra, Instituto de Investigación en Ciencias Ambientales (IUCA), Universidad de Zaragoza, Pedro Cerbuna, 12, E-50009 Zaragoza, Spain.

5 Dipartimento di Scienzedella Terra "A. Desio", Universitàd degli Studi di Milano, via Mangiagalli 34, 20133 Milano, Italy.

* Corresponding author: Christian.Linnert@ruhr-uni-bochum.de
} 


\section{Introduction}

The early Late Cretaceous (Cenomanian-Turonian) was characterised by one of the warmest palaeoclimates of the past 140 million years ('hothouse climate': Wilson et al. 2002, Hay 2008, 2011, Friedrich et al. 2012, Kidder and Worseley 2012, MacLeod et al. 2013). This Cenomanian-Turonian world likely featured ice-free polar regions (Barron et al. 1981, Barron 1983, Ladant and Donnadieu 2016), tropical and subtropical sea-surface temperatures (SSTs) warmer than $35^{\circ} \mathrm{C}$ (Forster et al. 2007, Bornemann et al. 2008, Sinninghe Damsté et al. 2010, MacLeod et al. 2013) and a shallow latitudinal temperature gradient (Huber et al. 1995, 2002, Bice et al. 2003, Hay and Floegel 2012). By contrast, the late Turonian-Maastrichtian is considered an interval of global cooling (e.g., Clarke and Jenkyns 1999, Linnert et al.2014), possibly driven by declining atmospheric $p \mathrm{CO}_{2}$ (e.g., Jenkyns et al. 1994, Berner and Kothavala 2001, Tabor et al. 2016). This decrease in $p \mathrm{CO}_{2}$ may have been the result of reduced rates of mid-ocean ridge and large igneous province activity (Larson 1991, Coffin et al. 2006). Additionally, the reconfiguration of oceanic gateways may have affected deep-water circulation and oceanic heat transport. For example, it has been suggested that opening of the Equatorial Atlantic Seaway contributed to Late Cretaceous cooling by allowing cool southerncomponent waters to enter the warm North Atlantic Basin (e.g. Frank and Arthur 1999, Friedrich et al. 2012).

The Campanian is a key interval in the Late Cretaceous, as it marks the transition between the mid-Cretaceous 'hot greenhouse' and the 'cool greenhouse' of the Maastrichtian and early Paleocene (Clarke and Jenkyns 1999, Zachos et al. 2008, Friedrich et al. 2012, Ando et al. 2013, Linnert et al. 2014, Falzoni et al. 2016). The cooling was accompanied by changes in global oceanic circulation towards a mode of deepwater formation in high southern latitudes, although the precise timing and geographic influence of these changes is still being revealed (Barrera and Savin 1999, Frank and Arthur 1999, Huber et al. 2002, Cramer et al. 2009, Robinson et al. 2010, MacLeod et al. 2011, Friedrich et al. 2012, Martin et al. 2012, Robinson and Vance 2012, Murphy and Thomas 2012, 2013, Jung et al. 2013, Voigt et al. 2013, Moiroud et al. 2013, 2016, Donnadieu et al. 2016). Changes in the location and style of deep-water formation have been considered as possible triggers for perturbations of the global carbon cycle, such as the Campanian-
Maastrichtian Boundary Event (CMBE; Friedrich et al. 2009). However, other factors, such as eustatic sealevel falls (Jarvis et al. 2002, 2006), a reduced rate of organic-matter flux (Friedrich et al. 2009) and tectonic processes (Voigt et al. 2010,2012) may also have contributed.

Here, we present new Campanian-Maastrichtian bulk-rock geochemical data $\left(\delta^{13} \mathrm{C}, \delta^{18} \mathrm{O}\right.$, TOC and $\% \mathrm{CaCO}_{3}$ ) from the Shuqualak-Evans core (Mississippi, USA). Linnert et al. (2014) published a record of SSTs from this site, which they argued was largely controlled by global climate change. The comparison of this dataset with new data from the same core enables us to discuss the carbon-isotope record with regard to general global climate evolution. This discussion may help us to answer the question of whether prominent carbon-isotope excursions around the late Campanian-early Maastrichtian interval are related to the general trend of palaeotemperatures.

\section{Geological setting and materials}

During the Campanian-Maastrichtian, the Mississippi embayment was a relatively shallow epicontinental sea (Fig. 1) that covered much of the modern states of Louisiana, Mississippi and Florida. The ShuqualakEvans core was drilled in Shuqualak, Mississippi, USA $\left(32^{\circ} 58^{\prime} 49^{\prime \prime} \mathrm{N}, 88^{\circ} 34^{\prime} 8^{\prime \prime} \mathrm{W}\right)$, recovering a nearcontinuous, $\sim 240 \mathrm{~m}$-thick sequence of mainly Campanian and Maastrichtian marine sediments (Fig.2). The base of the sequence $(\sim 253.2-252 \mathrm{~m}$ drilling depth) is characterised by glauconitic sandstones of latest Santonian-earliest Campanian age (Linnert et al. 2014). These sandstones are overlain by the lower Campanian Mooreville Formation ( 252-180 m), which is mainly composed of marls and marly chalk. The lower Campanian Arcola Limestone was recovered between $180 \mathrm{~m}$ and $175 \mathrm{~m}$. The interval from $\sim 175 \mathrm{~m}$ to $\sim 9 \mathrm{~m}$ belongs to the lower Campanianupper Maastrichtian Demopolis Formation and is dominated by marls and chalks (Fig. 2). Calcareous nannofossil and planktonic foraminiferal biostratigraphy (Linnert et al. 2014), suggests that most of the cored interval $(253.19 \mathrm{~m}-22.86 \mathrm{~m})$ was deposited during the Campanian (83.2-72 Ma), whereas the entire Maastrichtian $(72-66 \mathrm{Ma})$ is only represented by $13.41 \mathrm{~m}$ of sediment. For geochemical analyses, 160 samples were analysed from the core, at approximately $1.5 \mathrm{~m}$ resolution. 


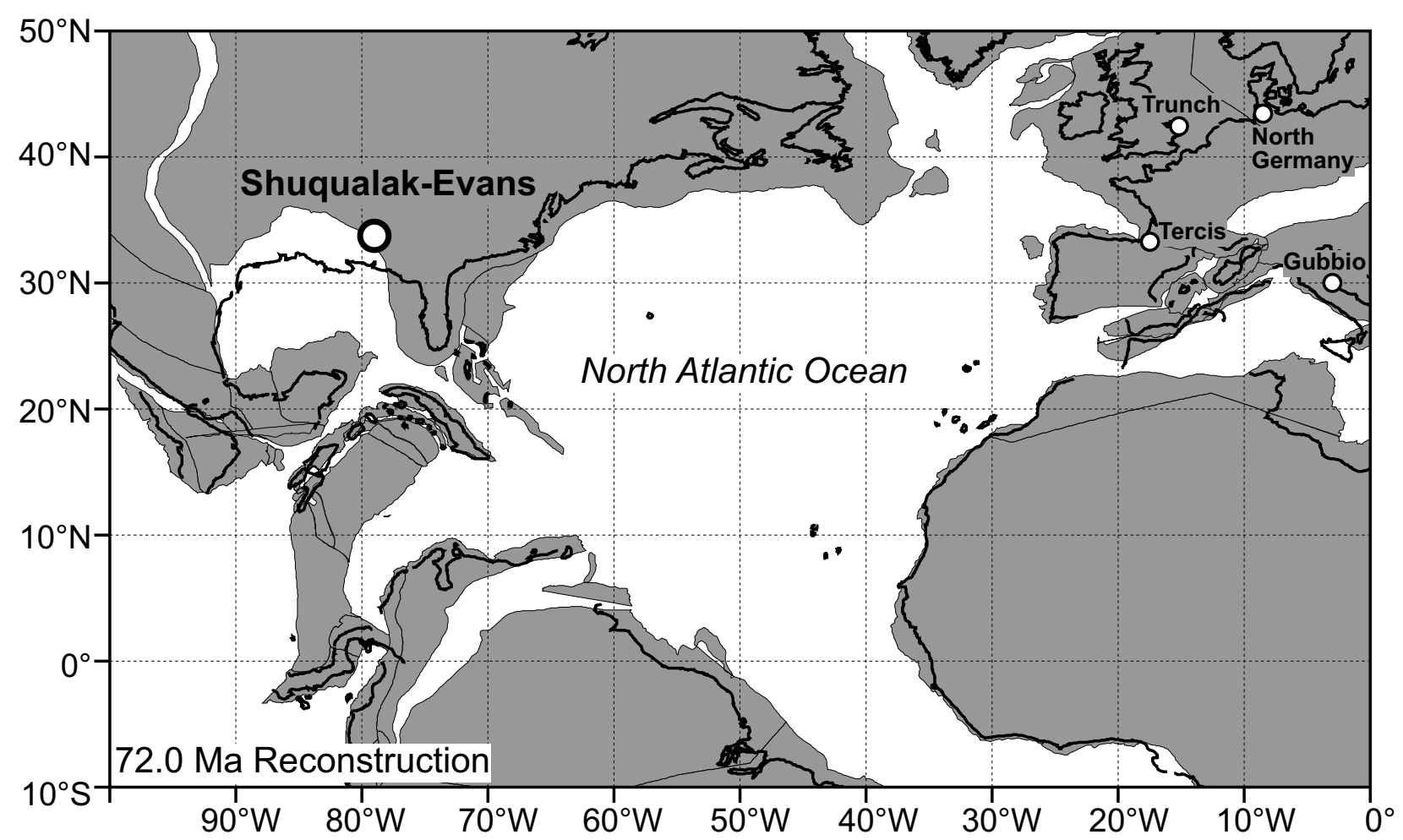

Fig. 1. Palaeogeographic map of the North Atlantic at $72.0 \mathrm{Ma}$ (continental plates blocked out in grey, thick black lines indicate Present Day coastlines) indicating the locality of Shuqualak and other sections (North Sea, Tethys) discussed in the text. Reconstruction adapted from the Ocean Drilling Stratigraphic Network (ODSN) palaeomap project (http://www.odsn. de/odsn/services/paleomap/paleomap.html)

In addition to the data from the Shuqualak-Evans core, we also provide new stable-isotope data from between $\sim 100 \mathrm{~m}$ and $150 \mathrm{~m}$ depth in the British Geological Survey Trunch core drilled through the English Chalk to increase the stratigraphic resolution through the Late Campanian carbon-isotope Event (LCE). The Trunch borehole is situated in Norfolk, UK and is one of the key records for Upper Cretaceous integrated stratigraphy (Jenkyns et al. 1994, Jarvis et al. 2002, 2006, Voigt et al. 2010, 2012).

\section{Methods}

\subsection{Carbonate content and TOC}

Total carbon (TC) and total organic carbon (TOC) were measured on each sample from the ShuqualakEvans core to aid interpretation of the geochemical data. Bulk powdered samples were obtained by drilling fresh rock surfaces with a $0.5-1 \mathrm{~mm}$ drill-bit. Samples were analysed using a Thermo Flash EA 1112 elemental analyser in the laboratories at University
College London (UCL). For the TOC analysis, each sample was decarbonated in a silver foil capsule, using $\sim 10 \%$ hydrochloric acid, and dried down on a hotplate. TC was measured on unacidified samples in aluminium foil capsules. Total inorganic carbon (TIC) was calculated by the subtraction of TOC from the TC. Then by assuming that TIC to be associated with $\mathrm{CaCO}_{3}$, it was possible to calculate $\% \mathrm{CaCO}_{3}$ by simply multiplying TIC by 8.3333 (recurring; the carbon represents 1/8.333 part of the $\mathrm{CaCO}_{3}$ ). Repeated analysis of internal standards suggest that the standard deviation on TC and TOC measurements is $\pm 0.1 \%$.

\subsection{Bulk carbonate stable isotopes $\left(\delta^{13} \mathrm{C}, \delta^{18} \mathrm{O}\right)$}

One hundred and fifty-seven bulk-carbonate samples from the Shuqualak-Evans core were analysed by continuous-flow mass spectrometry, using a Gasbench connected to a Thermo Finnegan Delta+ XP mass spectrometer in the Bloomsbury Environmental Isotope Facility (BEIF) at UCL. Three hundred and sixty-two samples from the Trunch core were collected, 


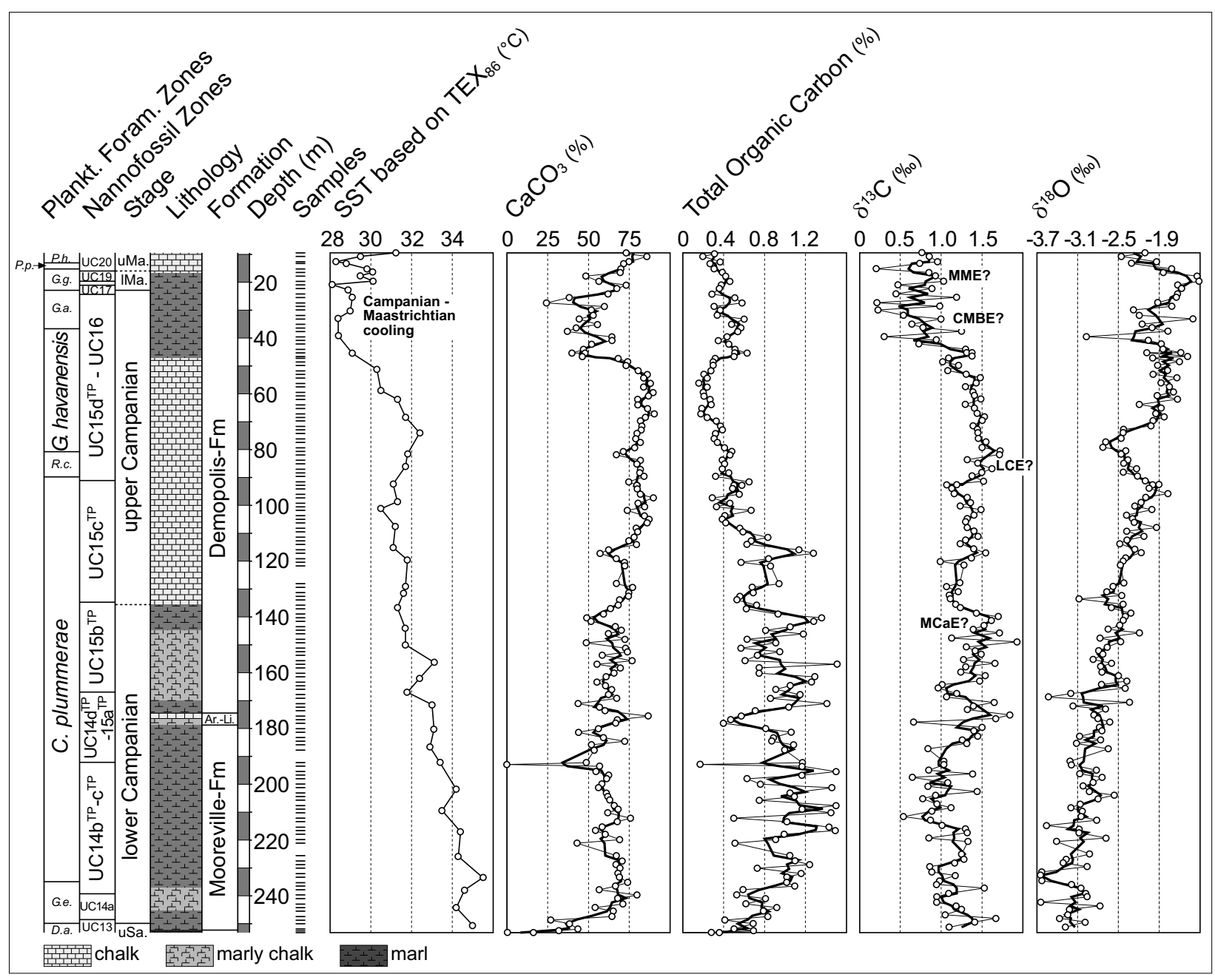

Fig. 2. Biostratigraphy, lithology and geochemistry of the Shuqualak-Evans core. Biostratigraphy and palaeo-SST estimates (based on TEX 86 ) after Linnert et al. (2014). Substages: uSa. - upper Santonian; 1Ma. - lower Maastrichtian; uMa. upper Maastrichtian. Carbon-isotope events: MCaE - Mid-Campanian Event; LCE - Late Campanian Event; CMBE - Campanian Maastrichtian Boundary Event; MME - Mid-Maastrichtian Event. Planktonic foraminiferal zones: D.a. - Dicarinella asymetrica; G.e.-Globotruncanita elevata; C.plummerae - Contusotruncana plummerae; R.c. - Radotruncana calcarata; G.havanensis - Globotruncanella havanensis; G.a. - Globotruncana aegyptiaca; G.g. - Gansserina gansseri; P.p. Pseudoguembelina palpebra; P.h. - Pseudoguembelina hariaensis.

where possible, every $10 \mathrm{~cm}$ between 99.2 and $152.3 \mathrm{~m}$ depth. These samples were analysed using a VG Isogas Prism II mass spectrometer with an on-line VG Isocarb common acid-bath preparation system at the Department of Earth Sciences, University of Oxford. All isotope data are reported in the standard delta notation $\left(\delta^{13} \mathrm{C}, \delta^{18} \mathrm{O}\right)$ in per-mil $(\%)$ values on the Vienna PDB (V-PDB) scale. One standard deviation error on internal standards at UCL was generally better than $\pm 0.05 \%$ o for $\delta^{13} \mathrm{C}$ and $\pm 0.10 \%$ o for $\delta^{18} \mathrm{O}$ and, at Oxford, was better than $\pm 0.1 \%$ ofor both $\delta^{13} \mathrm{C}$ and $\delta^{18} \mathrm{O}$.

\section{Results}

\section{1 $\mathrm{TOC}$ and $\mathrm{CaCO}_{3}$ values}

The stratigraphic variations in $\mathrm{TOC}$ and $\% \mathrm{CaCO}_{3}$ from the Shuqualak-Evans core are shown in Figure 2 and provided in Supplementary Table 1 . The glauconitic sandstone at the base of the core $(253.19-252.83 \mathrm{~m})$ is characterised by increasing carbonate content from $0.4 \%$ at $253.19 \mathrm{~m}$ to $16.2 \%$ at $252.83 \mathrm{~m}$. The TOC of the sandstone varies from $0.3-0.4 \%$. In the mostly marly Mooreville Formation (251.97-179.83 m), the 
carbonate content varies from $0.0 \%$ (at $192.94 \mathrm{~m}$ ) to $79.8 \%$ (at $239.27 \mathrm{~m}$ ); the TOC values vary from $0.2 \%$ (at $192.94 \mathrm{~m}$ ) to $1.5 \%$ (at $207.26 \mathrm{~m}$ and $195.07 \mathrm{~m}$ ). The chalky Arcola Limestone (178.31-175.26 m) is characterised by high carbonate content, from $66.6 \%$ (at $178.31 \mathrm{~m}$ ) to $86.8 \%$ (at $175.26 \mathrm{~m}$ ) and lower TOC content of $0.4 \%$ (at $178.31 \mathrm{~m}$ ) to $0.6 \%$ (at $175.26 \mathrm{~m}$ ). In the Demopolis Formation (173.74-9.45 m), the carbonate content is more variable, with values from $24.2 \%$ (at $27.43 \mathrm{~m}$ ) to $90.3 \%$ (at $67.06 \mathrm{~m}$ ). In the Demopolis Formation, the chalky interval from $114.30 \mathrm{~m}$ to $47.24 \mathrm{~m}$ is characterised by values higher than $67.1 \%$. In the marly interval from $46.94-18.29 \mathrm{~m}$, the $\mathrm{CaCO}_{3}$ content varies from $24.2 \%$ to $73.2 \%$. The TOC shows a similar variability, with values from $0.2 \%$ (at $56.39 \mathrm{~m}$ ) to $1.5 \%$ (at $156.97 \mathrm{~m}$ ).

\subsection{Stable isotopes $\left(\delta^{13} \mathrm{C}, \delta^{18} \mathrm{O}\right)$ from the Shuqualak-Evans core}

The stable-isotope records $\left(\delta^{13} \mathrm{C}, \delta^{18} \mathrm{O}\right)$ from the Shuqualak-Evans core are generally independent of changes in lithology (Figure 2; data in Supplementary Table 1). The lowest value of $\delta^{13} \mathrm{C}(-1.42 \%)$ was measured in the lowermost analysed sample, at $252.83 \mathrm{~m}$; this value rises to $1.10 \%$ in the next sample, at $251.46 \mathrm{~m}$. The interval from $251.46-211.84 \mathrm{~m}$ is characterised by variable carbon-isotope values, but there is also a distinct decreasing trend from $1.67 \%$ at $248.41 \mathrm{~m}$ to $0.54 \%$ at $211.84 \mathrm{~m}$. In the following sequence, from $211.84 \mathrm{~m}$ to $170.69 \mathrm{~m}$, the $\delta^{13} \mathrm{C}$ ratios are still highly variable, but they increase up to $1.84 \%$ at $175.26 \mathrm{~m}$. The next interval, from $169.16 \mathrm{~m}$ to
Fig. 3. Biostratigraphy, lithology and geochemistry of the Trunch core, Norfolk, UK. Biostratigraphy after Jenkyns et al. (1994), Jarvis et al. (2002) and Voigt et al. (2010, 2012). Macrofossil zones: B.lanceolata Belemnella lanceolata; O.pilula - Offaster pilula; M.tes. - Marsupites testudinarius.

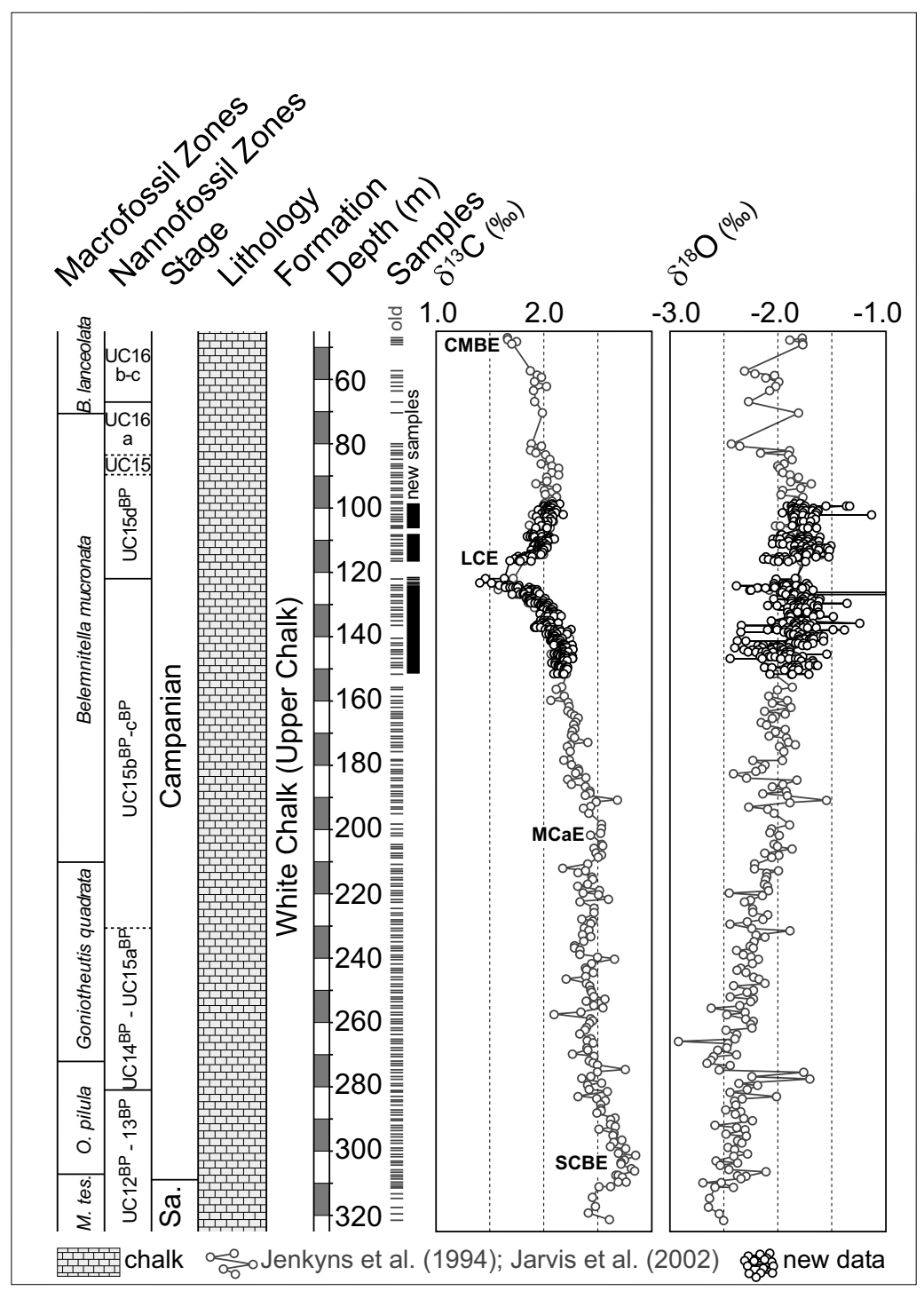


$140.21 \mathrm{~m}$, starts with relatively low values of around $1.00 \%$ (lowest $0.97 \%$ at $166.12 \mathrm{~m}$ ), but these values increase again towards $1.70 \%$. From $138.66 \mathrm{~m}$ to $92.81 \mathrm{~m}$, the $\delta^{13} \mathrm{C}$ data are generally lower, but more stable than in the older sediments; the lowest values were measured in the intervals from $137.16 \mathrm{~m}$ to $120.20 \mathrm{~m}$ (down to $0.99 \%$ ) and from $96.01 \mathrm{~m}$ to $92.81 \mathrm{~m}$ (down to $1.07 \%$ ). The interval from $91.44 \mathrm{~m}$ to $53.34 \mathrm{~m}$ is characterised by less-variable, but higher, $\delta^{13} \mathrm{C}$ ratios, ranging from $1.30 \%$ (at $64.01 \mathrm{~m}$ ) to $1.72 \%$ o (at $80.77 \mathrm{~m}$ ). From $53.34 \mathrm{~m}$, the carbon-isotope data show another trend of decreasing values, which continues towards the top of the ShuqualakEvans core. In this interval, the values become highly variable again, ranging from $0.21 \%$ (at $15.24 \mathrm{~m}$ ) to $1.38 \%$ (at 46.94-45.72 m).

The $\delta^{18} \mathrm{O}$ record also starts with the lowermost value $(-5.82 \%$ o $)$ at $252.83 \mathrm{~m}$, jumping to $-3.28 \%$ in the next sample at $251.46 \mathrm{~m}$. From this sample upwards, $\delta^{18} \mathrm{O}$ shows a distinctive trend towards higher values, up to $96.01 \mathrm{~m}\left(-1.77 \%\right.$ ) . The $\delta^{18} \mathrm{O}$ record then decreases down to $-2.73 \%$ at $79.25 \mathrm{~m}$ and increases again towards $-1.48 \%$ at $46.94 \mathrm{~m}$. The $\delta^{18} \mathrm{O}$ values are highly variable in the highest part of the sequence (46.94-9.45 m), with minimum to maximum values ranging from $-2.97 \%$ o (at $39.62 \mathrm{~m}$ ) to $-1.32 \%$ (at $19.81 \mathrm{~m}$ ). Both isotopic signatures of the ShuqualakEvans core are given in Figure 2.

\subsection{Stable isotopes $\left(\delta^{13} \mathrm{C}, \delta^{18} \mathrm{O}\right)$ from the Trunch core}

The new stable-isotope data from the Trunch core (Supplementary Table 2) agrees well with previously published data (Figure 3; Jenkyns et al. 1994). The higher resolution carbon-isotope stratigraphy of the LCE suggests that the magnitude of this event may have been slightly larger (by about $0.2 \%$ ) than estimated from the low-resolution dataset, but otherwise the new data do not significantly alter the view of the LCE.

\section{Discussion}

\subsection{Is a primary carbon-isotope signal preserved in the Shuqualak-Evans core?}

Before interpreting bulk-carbonate carbon-isotope data from the Shuqualak-Evans core as a primary seawater signal, it is necessary to consider whether sec- ondary effects, such as the reworking/variable input of calcareous sediments and diagenesis, may have influenced the $\delta^{13} \mathrm{C}$ data. The lack of evidence for reworking of pre-Campanian calcareous nannofossils and planktonic foraminifera (Linnert et al. 2014) indicates no significant deposition of allochthonous carbonates. There is little evidence for carbonate diagenesis from calcareous nannofossils and planktonic foraminifera because assemblages are almost exclusively very well preserved throughout the studied section. Only in the uppermost part of the studied section (9.45-22.86 m) does nannofossil preservation decline, although even here it is still relatively good. A reduction in the quality of carbonate preservation in this uppermost part of the core may also be indicated by more variable carbonisotope values, which are possibly related to some degree of recrystallisation. Such an increased variability of $\delta^{13} \mathrm{C}$ data is observed for the interval below $148 \mathrm{~m}$ and for samples above $50 \mathrm{~m}$, both intervals of relatively low $\mathrm{CaCO}_{3}$ and high TOC content (Fig.2). These lower carbonate values may indicate an increased dilution by non-carbonate components, or a change in carbonate productivity, possibly driven by factors such as changing terrestrial run-off or surface-water circulation patterns. The carbon-isotope values are generally consistent with those of other Upper Cretaceous pelagic marls and chalks, and hemipelagic deposits, all interpreted as representing primary seawater signals (e. g., Jenkyns et al. 1994, Jarvis et al. 2002, 2006, Li et al. 2006, Voigt et al. 2010, 2012, Wendler et al. 2011), albeit $0.5-1 \%$ lighter.

The $\delta^{18} \mathrm{O}$ values are generally consistent with carbonate formed from seawater, and are not anomalously isotopically light, as would be expected if the carbonate had been affected by extensive meteoric, or extreme burial, diagenesis. However, one data-point (occurring in the glauconitic sandstone at the base of the core) has distinctly lower $\delta^{13} \mathrm{C}$ and $\delta^{18} \mathrm{O}$ values compared to the rest of the dataset. This single data point may derive from carbonate that is not entirely marine in origin (the lithology of this sample indicates shallower-water deposition), and so is not included in the discussion of carbon-isotope stratigraphy that follows. Excluding this one sample, there is no significant correlation between $\delta^{13} \mathrm{C}$ and $\delta^{18} \mathrm{O}$ (Figure 4a), which suggests that the carbon-isotope data have not been affected by diagenesis, and so can be interpreted as a primary recorder of sea-water $\delta^{13} \mathrm{C}$ (as discussed in many previous publications, including Veizer 1983 and Sharp 2006). Furthermore, cross-plots between geochemical $\left(\delta^{13} \mathrm{C}, \delta^{18} \mathrm{O}\right)$ and lithological data $\left(\mathrm{CaCO}_{3}\right.$, 

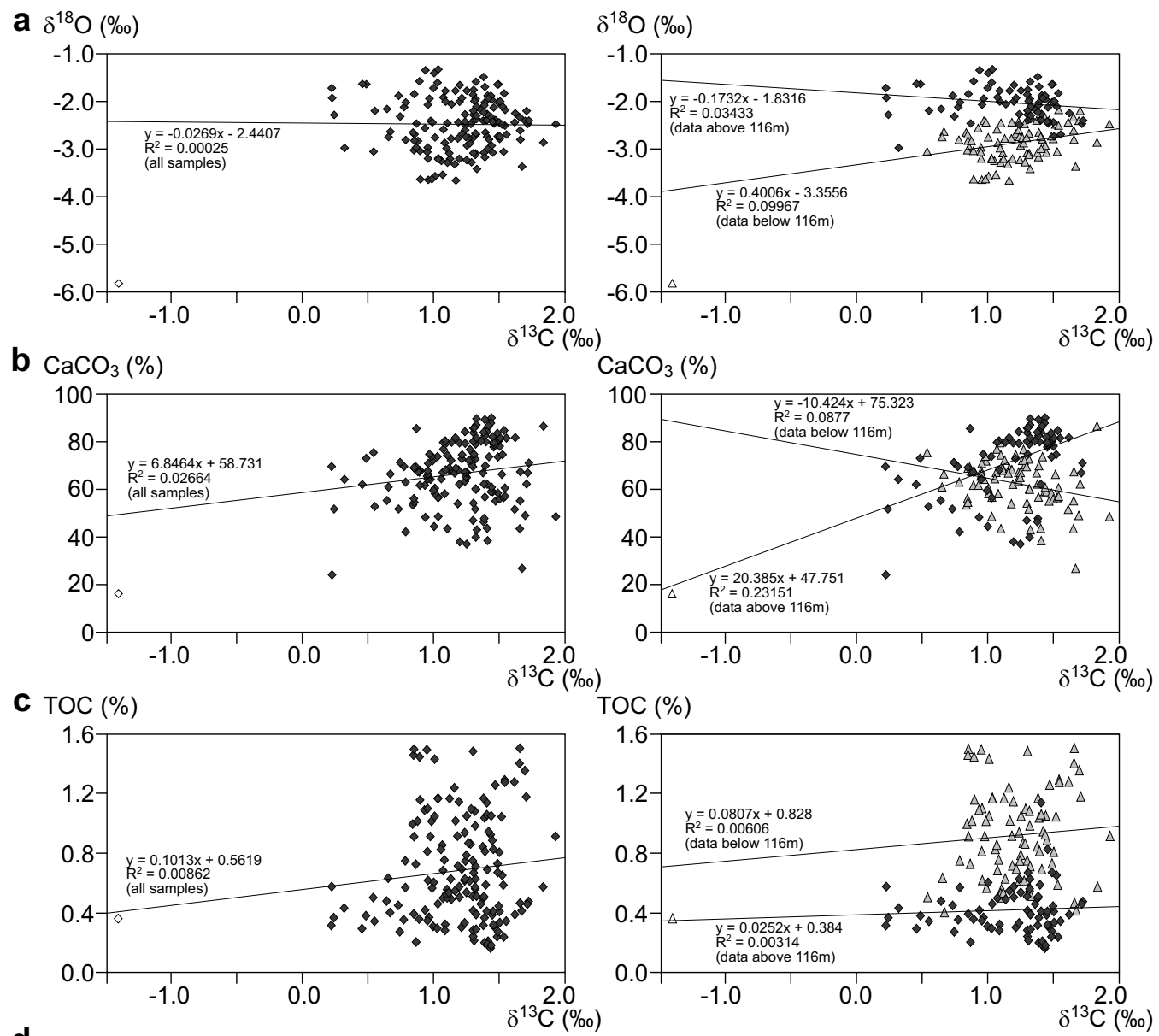

TOC (\%)
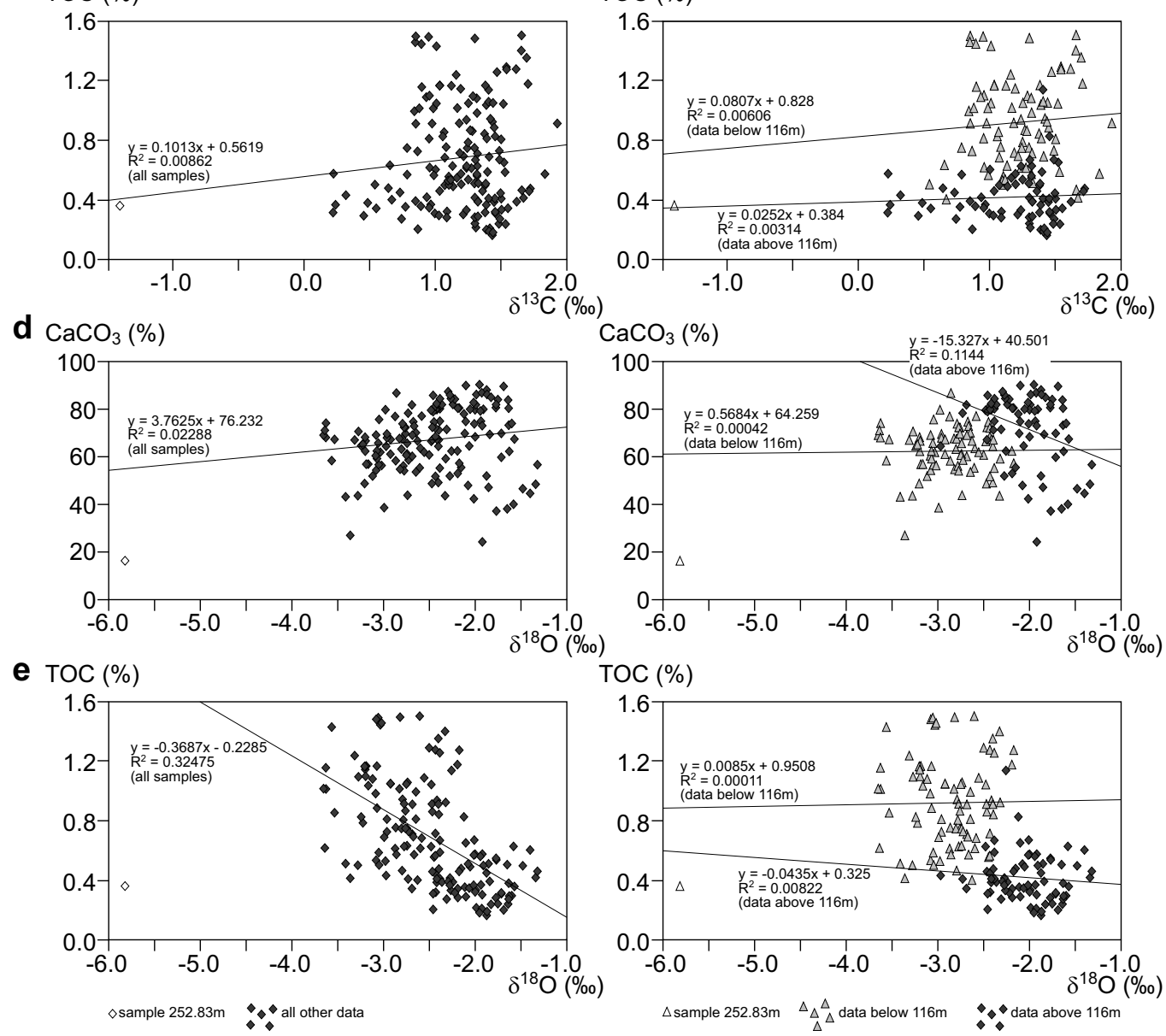

TOC $(\%)$

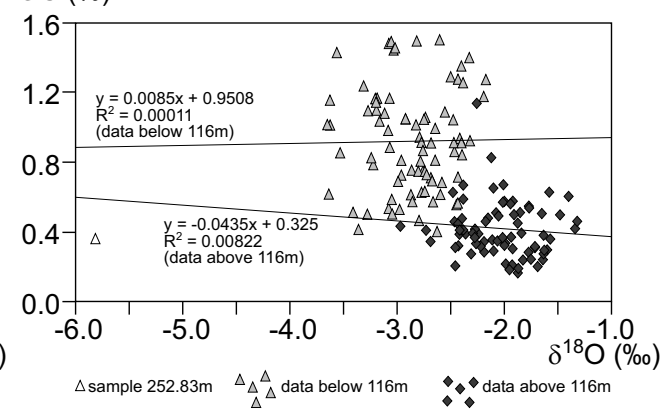

Fig. 4. Cross-plots of $\delta^{13} \mathrm{C}$ (a) $v s \delta^{18} \mathrm{O}$, (b) $v s \% \mathrm{CaCO}_{3}$, (c) $v s$ TOC and $\delta^{18} \mathrm{O}$, (d) $v s \% \mathrm{CaCO}_{3}$, (e) $v s \mathrm{TOC}$. In the crossplots on the left, linear regressions and $\mathrm{R}^{2}$-values were calculated for all measured samples, excluding sample $252.83 \mathrm{~m}$; on the right, those regressions were calculated individually for all samples below $116 \mathrm{~m}$ (combined interval of highly variable carbon-isotope data below $148 \mathrm{~m}$ and low $\delta^{13} \mathrm{C}$ values between $148 \mathrm{~m}$ and $116 \mathrm{~m}$ ) and for all samples above $116 \mathrm{~m}$ (interval of interest containing the LCE and CMBE CIEs). 
TOC) support the assertion that no strong diagenetic effect has influenced the isotopic values, as there is no significant correlation between any of these parameters (Figure $4 b-e$ ).

\subsection{Carbon-isotope stratigraphy and refinement of the age-model for the Shuqualak-Evans core}

Previous high-resolution studies of Upper Cretaceous carbon-isotope stratigraphy (e.g. Jarvis et al. 2002, 2006, Voigt et al. 2010, 2012, Thibault et al. 2012a, b, Wendler 2013) have revealed five to seven stratigraphically significant carbon-isotope excursions (CIEs) in the Santonian-Maastrichtian interval. These excursions include the Santonian-Campanian Boundary Event (SCBE, positive excursion), the LCE (negative excursion), the CMBE (negative excursion), the MidMaastrichtian Event (MME, a two step positive excursion) and the Cretaceous-Paleogene Boundary Event (KPgE, major negative excursion; e.g. Jarvis et al. 2002, Voigt et al. 2010, 2012). Further isotopic anomalies are described in the work of Jarvis et al. (2002) and Thibault et al. (2012a, b), including the Mid-Campanian Event (MCaE, positive excursion) and the latest Campanian Epsilon Event (CEE, negative excursion).

The uppermost $\sim 40 \mathrm{~m}$ of the Shuqualak-Evans core are difficult to correlate with certainty, due to the relatively condensed nature of the Maastrichtian sequence (Linnert et al. 2014). Carbon-isotope values are generally relatively light, albeit with some scatter. Slightly higher $\delta^{13} \mathrm{C}$ values between $\sim 16 \mathrm{~m}$ and $20 \mathrm{~m}$ may correlate with the MME, as the base occurrence of Lithraphidites quadratus (nannofossil) is at $16.76 \mathrm{~m}$, which is associated with the MME elsewhere (Voigt et al. 2012).

The most striking feature of the carbon-isotope record is the shift towards more negative $\delta^{13} \mathrm{C}$ values between $50 \mathrm{~m}$ and $40 \mathrm{~m}$ depth (Figs. 2, 4). Above this transition, at approximately $23 \mathrm{~m}$ depth, Linnert et al. (2014) reported top Uniplanarius trifidus, top Tranolithus orionatus (nannofossils) and base Gansserina gansseri (planktonic foraminifer) (Fig.5). Voigt et al. (2012) discussed the relative merits of these biostratigraphic markers and suggested that all three are closely associated with the CMBE, indicating that the negative excursion between $50 \mathrm{~m}$ and $40 \mathrm{~m}$ can be correlated with the onset of this global CIE.

A second small negative excursion, which shows a similar magnitude to the LCE in European sections (including the high resolution record from the Trunch borehole; Figures 3 and 5) is observed in the Shuqualak-Evans core at $\sim 90-100 \mathrm{~m}$ depth. This isotope anomaly, however, occurs well below the bases of the two index taxa Radotruncana calcarata (planktonic foraminifer, $89.89 \mathrm{~m}$ ) and Uniplanarius trifidus (calcareous nannofossil, $91.44 \mathrm{~m}$; Linnert et al. 2014), which constrain the stratigraphic position of the LCE at other localities. According to data from those other localities, the LCE appears within (Gubbio, Italy and Shatsky Rise, NW Pacific), or above (Tercis, France and Tibet), the R.calcarata planktonic foraminiferal zone (Wendler et al. 2011, Voigt et al. 2012, Wendler 2013). Thus, it is unlikely that the $\delta^{13} \mathrm{C}$ excursion below $\sim 90 \mathrm{~m}$ represents the LCE, as defined by Voigt et al. (2012), unless a minor hiatus exists. However, based on the biostratigraphy, the LCE may be recorded in Shuqualak by a weak negative excursion $(\sim 82-$ $88 \mathrm{~m}$, Fig. 5) within the R.calcarata zone. If correct, then this would suggest a much less significant LCE, compared to the magnitude of the excursion in European sections.

An alternative definition for the LCE is given by Thibault et al. (2012a), who suggested a longer duration for the event, beginning with a small negative $\delta^{13} \mathrm{C}$ excursion, followed by a short recovery interval and, in the European sections, by a much more pronounced second negative excursion. A similar LCE definition is also used by Chenot et al. (2016), who termed the older, smaller peak the "pre-LCE" and the younger, larger excursion the "LCE main". The minor pre-LCE, which is closely associated with the base of U.trifidus, is well developed at Tercis and in northern Germany (see Fig.4 in Thibault et al. 2012a; see Figs. 3, 6 in Voigt et al. 2012). At Shuqualak, the preLCE excursion (Fig. 5) is perhaps represented by the distinctive isotope anomaly measured below $90 \mathrm{~m}$. In contrast to European sections, the LCE from Mississippi may begin with a well-pronounced pre-LCE, followed by a much weaker LCE main (Figs.5, 6). However, there are still some discrepancies about this interpretation and the position of the R.calcarata Zone because, in some European sections, the pre-LCE appears well within that biozone (e.g., Tercis; Thibault et al. 2012a, Voigt et al. 2012, Chenot et al. 2016), whereas in Shuqualak it lies below that biozone.

Some diachroneity of the R.calcarata biozone is perhaps related to local palaeoenvironmental stress (i.e. relatively shallow water depths, eutrophic vs. oligotrophic conditions, water mass stratification ...) affecting the stratigraphic appearance of $R$.calcarata. 

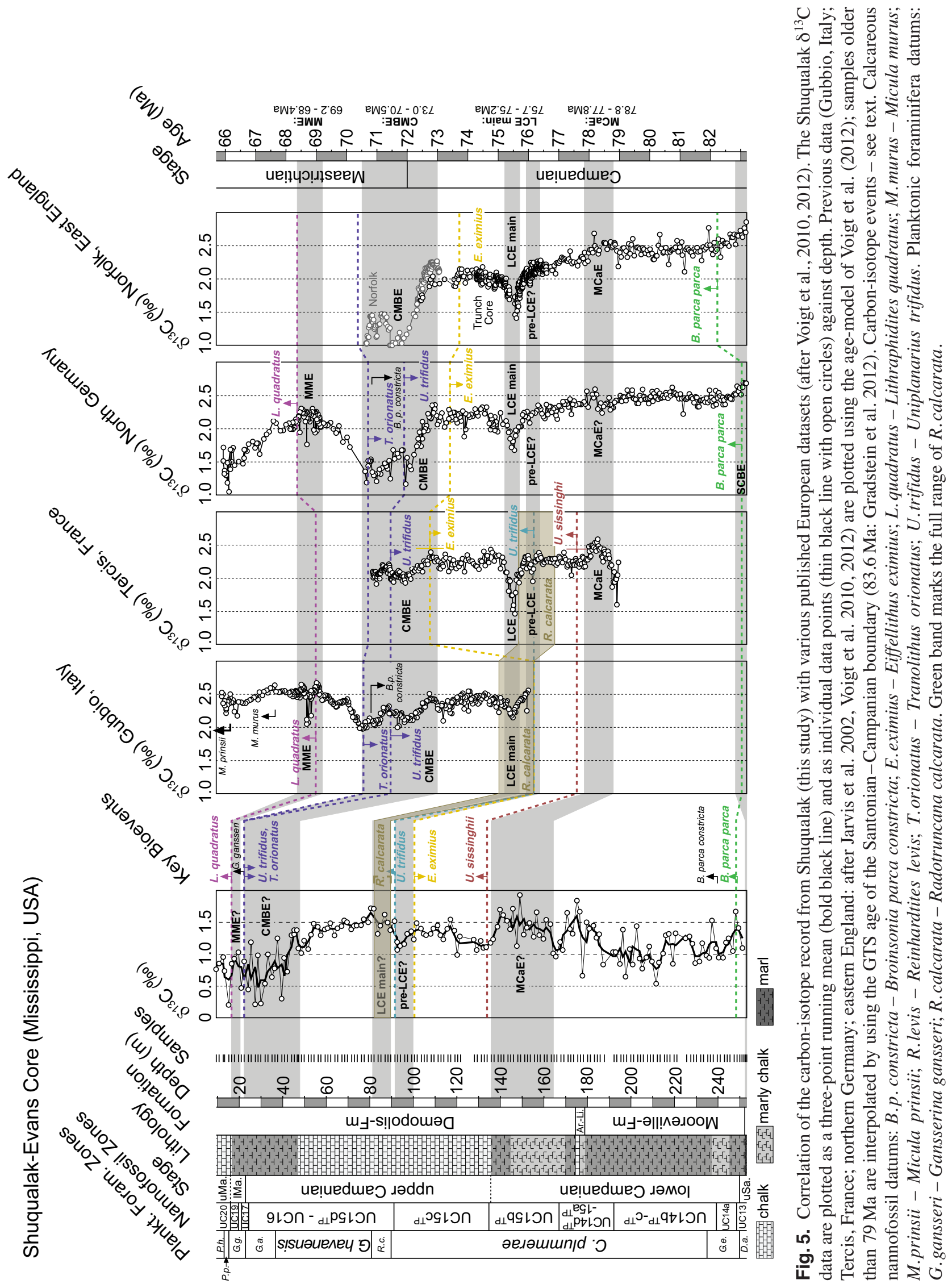
This is supported by the observation that the genera Globotruncana, Globotruncanita, and Globotruncanella, which are usually common in late Campanian deeper-water settings (Abramovich et al. 2003, 2010, Pérez-Rodríguez et al. 2012), are only represented in Shuqualak Evans by a few specimens each, suggesting conditions were not suitable for all planktonic foraminifera. Thus, it is possible that the stratigraphic range of R.calcarata is shorter in Shuqualak than in other North Atlantic localities due to local conditions.

The higher $\delta^{13} \mathrm{C}$ values below base $U$. sissinghii (at $134.11 \mathrm{~m}$; Fig. 5) may correlate with the MCaE, which was observable in the same stratigraphic position at Tercis (see Fig. 3 in Voigt et al. 2012). At Tercis, the lower boundary of the $\mathrm{MCaE}$ is defined by a negative excursion (see Fig. 4 in Thibault et al. 2012a). Such a negative peak is observed in the Shuqualak-Evans core at $\sim 165 \mathrm{~m}$. The $\mathrm{MCaE}$ is not as well constrained as the younger events, however, having only been previously documented in France (Thibault et al. 2012a) and England (Jenkyns et al. 1994, Jarvis et al. 2002). The older SCBE, which was originally described from below base Broinsonia parca subsp. parca (nannofossil) (Jarvis et al. 2002, Voigt et al. 2010), was not encountered in the Shuqualak carbon-isotope record, as only a few samples were measured below that bioevent $(248.41 \mathrm{~m})$. The sedimentary record below $248.41 \mathrm{~m}$ is increasingly discontinuous as the basal sediments are highly condensed, glauconite rich and interrupted by several hiatuses. Whereas sample $249.94 \mathrm{~m}$ is dated as Campanian, sample $251.46 \mathrm{~m}$ is supposedly of latest Santonian age due to the presence of the Santonian planktonic foraminifer Dicarinella asymetrica. The coeval occurrence of early Campanian nannofossil species Arkhangelskiella cymbifomis in the same samples $(251.46-253.19 \mathrm{~m})$ suggests that the basal sediments from Shuqualak were deposited during the Santonian-Campanian transition.

Our isotope calibration of the Shuqualak-Evans core implies that the age-model published in Linnert et al. (2014) should be subtly refined, especially for the late Campanian-early Maastrichtian interval. In addition to calcareous nannofossil and planktonic foraminifer bioevents, the new model also considers the onset of the CMBE as a tie point, which was, following Voigt et al. (2012), set to $73 \mathrm{Ma}$. Our revised agemodel (Fig. 6 and Supplementary Table 3) suggests that sedimentation rates were highest in the early Campanian $(\sim 2.8 \mathrm{~cm} / \mathrm{kyr}$ for the interval $251.5-84 \mathrm{~m})$, decreased during the late Campanian $(\sim 1.3 \mathrm{~cm} / \mathrm{kyr}$ for the interval $84-29 \mathrm{~m}$ and $\sim 0.5 \mathrm{~cm} / \mathrm{kyr}$ for the inter- val 29-17 m) and were lowest in the Maastrichtian $(\sim 0.2 \mathrm{~cm} / \mathrm{kyr})$.

\subsection{The local depositional environment and its influence on the $\delta^{13} \mathrm{C}$ record}

Voigt et al. (2012) discussed how the magnitude of the latest Cretaceous CIEs vary regionally, perhaps due to local environmental overprints on the global CIEs. For example, the largest magnitude of the CMBE, greater than $1 \%$, was measured in shallow-shelf sections from the North Sea area (Trunch and the Norfolk coast; northern Germany; Stevns-1, Denmark) and in deep-waters of the Southern Ocean. Lower magnitudes were observed in Tethyan and Pacific sections (Gubbio, Tercis, and Ocean Drilling Program Site 1210 on Shatsky Rise in the NW Pacific; Voigt et al. 2012). The magnitude of the CMBE $(\sim-1.0 \%)$ in the Shuqualak-Evans record is similar to that observed in the North Sea area (Voigt et al. 2012) and is consistent with similar shelf palaeoenvironments. This relatively high value provides further support for the idea postulated by Voigt et al. (2012), that shallow-marine carbon reservoirs were more sensitive to local processes, such as the local oxidation of organic matter, than open-ocean sites. Furthermore, local palaeoceanographic conditions in the Mississippi embayment (e.g., productivity, remineralisation in the water column, surface-water mass circulation patterns from areas with low surface $\delta^{13} \mathrm{C}$ ) may, in conjunction with differential diagenesis, explain why the ShuqualakEvans core exhibits $\delta^{13} \mathrm{C}$ values that are typically 0.5 to $1 \%$ less than coeval strata elsewhere.

\subsection{Testing theories about palaeoenviron- mental triggers of the CMBE and LCE}

Even though the CMBE is well known from various localities around the world (Jarvis et al. 2002, Voigt et al. 2010, 2012, Thibault et al. 2012a, b, Jung et al. 2013), there is still ongoing controversy concerning the causal mechanisms. At Shuqualak, the direct comparison of carbon isotope data with palaeo-SST estimates $\left(\right.$ TEX $_{86}$; Linnert et al. 2014) reveals that the CMBE is linked to the latest Campanian cooling. The isotope perturbation was associated with an interval of minimum SSTs, but commenced roughly 1-2 Myrs after the onset of the cooling event (Fig. 6). This observation from Shuqualak confirms previous results from the tropical Pacific (e.g. Jung et al. 2013), which also suggested a lag of approximately $1 \mathrm{Myr}$ between the 

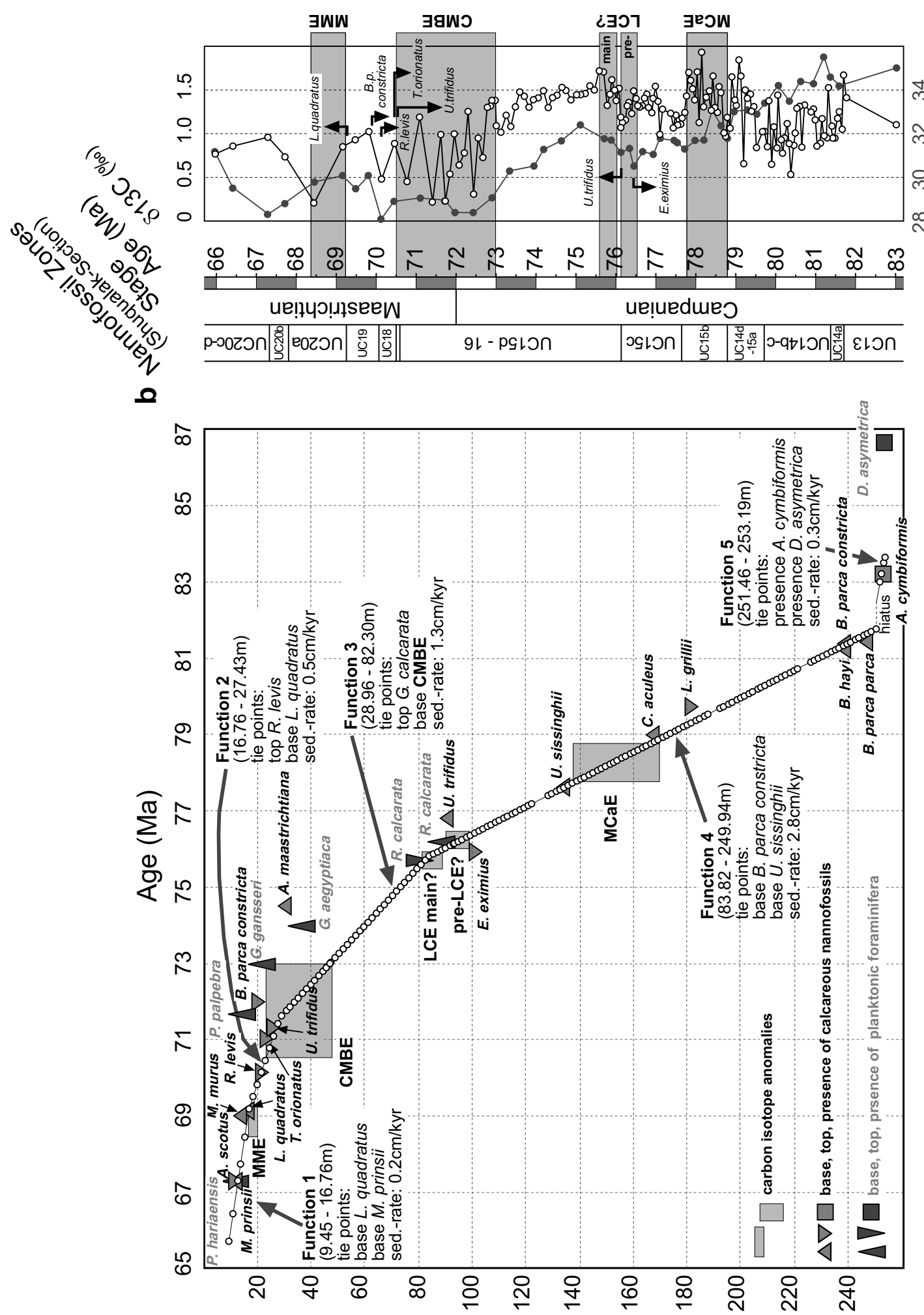

$\sigma$

(w) पldəa

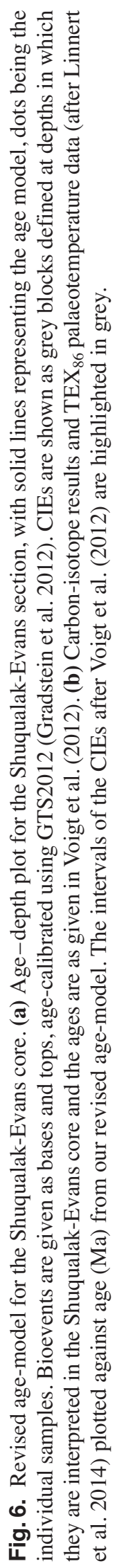


onset of temperature change and the isotope excursion. This indicates that the temporal offsets between temperature change and carbon cycling during the CMBE were not restricted to the Pacific Ocean but were likely a global phenomenon. Such a relationship provides an important constraint on the processes triggering the CMBE.

Jarvis et al. $(2002,2006)$ suggested that the CMBE was mainly the consequence of eustatic sea-level falls, promoting lowland erosion and the oxidation of organic matter. It has been suggested that the eustatic sealevel falls were caused by the thermal contraction of the water-column, due to global cooling or by glacioeustasy (e.g., Barrera et al. 1997, Miller et al. 1999, 2005, Browning et al. 2008). However, a glacial-eustatic mechanism seems unlikely given the lag between the onset of cooling and the CMBE. A lag of approximately 1 Myr is too long to be consistent with the build up of continental ice-sheets and sea-level fall, as this would likely have occurred over some tens of thousands of years. Similarly, the temporal lag also precludes sea-level falls due to thermal contraction of the water-column, given that the cooling and lag are observed in both SST and bottom-water records. Further arguments against a glacio-eustasic model are given by relatively warm deep-water temperatures $\left(6-10^{\circ} \mathrm{C}\right.$; Huber et al. 1995, 2002, Miller et al. 2005, Friedrich et al. 2012), warm Arctic Ocean SSTs (Jenkyns et al. 2004), cool-temperate mean annual air temperatures on the Antarctic Peninsula $\left(>7^{\circ} \mathrm{C}\right.$; Francis and Poole 2002, Kemp et al. 2014) and the relatively long duration (>2 myr) of the CMBE (Voigt et al. 2012). Although other mechanisms of driving sea-level change in the Cretaceous have been proposed (recently discussed by Wagreich et al. 2014, Sames et al. 2016, Wendler and Wendler 2016), such as "limno-eustasy" or "aquifer-eustasy", these mechanisms also seem unlikely, given the duration of the CMBE and the lag between climatic and carbon-cycle events.

Alternatively, it has been suggested that CIEs in the Campanian-Maastrichtian (e.g., CMBE) were the result of large-scale, solid-earth processes related to changes in plate tectonic configuration, subduction or hot-spot volcanism (Frank and Arthur 1999, Voigt et al. 2012, Jung et al. 2013). The long lag time between cooling and the onset of the CMBE may support such an explanation, as both climate change and carboncycle perturbation may have been coupled to certain stages of the same long-term tectonic change. For example, via the alteration of ocean circulation and ocean chemistry, solid earth processes could have in- fluenced the production, preservation and burial of organic and carbonate carbon in shelf and deep-sea settings, and consequently the isotopic composition of the ocean-atmosphere reservoir (discussed in Jarvis et al. 2002). The exact nature of these changes in carbon cycling were likely rather complex, due to the interactions between relatively long-term changes in boundary conditions (e.g., changes in spreading rate and opening of gateways; Larson 1991, Frey et al. 2000, Coffin et al. 2002, Müller et al. 2008) and shorter term processes (e.g. reconfiguration of ocean circulation, changes in bottom-water chemistry: Barrera and Savin 1999, Friedrich et al. 2009, Robinson et al. 2010, Robinson and Vance 2012, Murphy and Thomas 2012, 2013, Jung et al. 2013).

What is clear is that the currently available data for the Campanian-Maastrichtian events cannot be reconciled with a simplistic interpretation of the carbon-isotope data alone. Commonly invoked mechanisms for negative CIEs, such as, oxidation of organic carbon, release of methane hydrates, and increased volcanism, would all lead to an increase in $\mathrm{CO}_{2}$ in the ocean-atmosphere carbon reservoir that would be expected to cause synchronous warming during the negative $\delta^{13} \mathrm{C}$ event. However, warming is not observed; on the contrary, there is evidence from Mississippi (Linnert al. 2014), the Pacific Ocean (Jung et al. 2013), northern Germany (Voigt et al. 2010) and the Indian Ocean (Clarke and Jenkyns 1999, Falzoni et al. 2016) that the CMBE is linked to an interval of relatively cool temperatures. The significant duration of this negative CIE during the Campanian-Maastrichtian, compared, for example, to Palaeogene hyperthermals, allows other mechanisms of perturbing the carbon cycle to be explored. A mechanism must be invoked that does not cause a rise in atmospheric $\mathrm{CO}_{2}$, but does cause a small negative $\delta^{13} \mathrm{C}$ excursion in DIC globally and, for the CMBE at least, a drop in atmospheric $\mathrm{CO}_{2}$ (see Hasegawa et al. 2003).

At present, it is difficult to ascribe a precise solution, but it is interesting to note that a number of studies have suggested that the CMBE was associated with an increased influence of southerly-sourced deepwaters (e.g. Barrera and Savin 1999, Frank and Arthur 1999, Jung et al. 2013). Most of these models suggest that the latest Cretaceous cooling raised the latitudinal thermal gradient, which led to an increase in the influence of global deep-water masses formed in southern high-latitude sources (Huber et al. 1995, 2002, Linnert et al. 2014). The presence of well-oxygenated southerly deep-waters could have resulted in a better ventilat- 
ed and less corrosive deep-ocean. If so, average rates of global organic-carbon respiration and carbonate burial would have increased, assuming that they were not offset by a slowing of deep-ocean circulation elsewhere. These rate changes would have had the effect of reducing organic-carbon burial rates, relative to carbonate burial, and thus reducing $\delta^{13} \mathrm{C}$ values (Jarvis et al. 2002). A simple isotopic mass balance (e.g., the approach of Kump and Arthur 1999) shows that decreasing organic-carbon burial rates necessitates an increase in carbonate burial with an isotopically lighter value, assuming all other fluxes and reservoirs remain constant. Additional carbon-cycle and earth-system modelling is required to ascertain whether this mechanism can account for the CMBE and the absence of warming during that negative CIE over appropriate timescales.

The LCE is more difficult to explain, as it shows different patterns in Europe and North America (see discussion above). Our data from Shuqualak indicate that, around the LCE, there is a cooling event, but the difficulties of correlating Shuqualak with other records precludes a more definitive assessment. If our correlation is correct, then the relationship between the LCE and climate may be similar to that invoked for the CMBE, with a similar lag between climate change and carbon cycling (Fig.6). An alternative model for the LCE (both pre-LCE and LCE main) proposed by Chenot et al. (2016) invokes a relationship between these CIEs and an interval of enhanced weathering in Europe and parts of the Tethyan Realm. This enhancement of weathering was perhaps the consequence of tectonic activity, a sea-level lowstand (Chenot et al. 2016) or a more humid climate. Two of these possible factors (tectonics, local climate) are region-dependent; thus they may have had different patterns in Europe and in North America. Differences in those factors may have therefore been responsible for the different shapes of the LCE in different oceanographic regions. Further local palaeoenvironmental parameters, that may have also caused different patterns in the carbonisotope record, include water depth, productivity, remineralisation in the water column, surface-water mass circulation patterns from areas with low surface $\delta^{13} \mathrm{C}$, and 'seawater ageing' (e.g., Holmden et al. 1998, Voigt et al. 2012).

\section{Conclusion}

The Campanian-Maastrichtian carbon-isotope record from the Shuqualak-Evans core contains local expressions of the MCaE, the LCE, the CMBE and the MME, thereby adding to evidence from the Atlantic, Pacific and Tethyan Oceans for the global significance of these CIEs. The comparison of carbon-isotope and TEX $_{86}$ data demonstrates that two of these events (LCE, CMBE) occurred during intervals of cooler temperatures, suggesting a possible role for climate change in their genesis. However, significant temporal offsets between the cooling of both bottom and surface waters and the negative CIEs suggest that a simple cause-and-effect relationship, such as might be imagined through glacio-eustasy, is unlikely. Rather, in keeping with some previous studies, we suggest that both these CIEs were the result of a more protracted sequence of events linking tectonic (sea-floor spreading, oceanic gateways), palaeoclimatic (CampanianMaastrichtian cooling) and palaeoceanographic processes. An altered global oceanic circulation may have then affected bottom-water chemistry, leading to changes in the global ratio of carbonate to organiccarbon burial that ultimately drove the negative CIEs. However, unlike some negative CIEs in Earth history (e.g. the Paleocene-Eocene Thermal Maximum), there is no sign of global warming and no evidence for excess carbon input into the atmosphere during the CMBE and LCE intervals. The Late Cretaceous events described here clearly demonstrate that not all negative carbon-isotope excursions conform to the same model and that a better understanding of all these events is required to improve the interpretations of small negative CIEs throughout Earth history.

Acknowledgements. We thank Kevin Stevens for his thoughtful discussions and suggestions about the subject of isotope geochemistry. The support in the BEIF at UCL of Tony Osborn, Dorinda Ostermann and Tim Atkinson is gratefully acknowledged. Financial support is acknowledged from the German Science Foundation (DFG Research Stipend Li 2177/1-1 to CL), a Royal Society (UK) URF (to SAR), a NERC (UK) grant (to JAL and PRB), The Curry Fund of UCL (to CL), and MINECO/FEDER, UE (under project CGL2015-64422-P to JAA, SAR). We are very grateful to David Dockery from the Office of Geology, Mississippi Department of Environmental Quality for facilitating access to the Shuqualak-Evans core, to the late Ernie Russell for alerting us to the existence of this material, and to the British Geological Survey for allowing sampling of the Trunch core. 


\section{References}

Abramovich, S., Keller, G., Stüben, D., Berner, Z., 2003. Characterization of late Campanian and Maastrichtian planktonic foraminiferal depth habitats and vital activities based on stable isotopes. Palaeogeography, Palaeoclimatology, Palaeoecology 202, 1-29.

Abramovich, S., Yovel-Corem, S., Almogi-Labin, A., Benjamini, C., 2010. Global climate change and planktic foraminiferal response in the Maastrichtian. Paleoceanography 25, PA2201.

Ando, A., Woodard, S.C., Evans, H.F., Littler, K., Herrmann, S., MacLeod, K. G., Kim, S., Khim, B.-K., Robinson, S. A., Huber, B. T., 2013. An emerging palaeoceanographic 'missing link': Multidisciplinary study of rarely recovered parts of a deep-sea Santonian-Campanian transition from Shatsky Rise. Journal of the Geological Society $170,381-384$.

Barrera, E., Savin, S.M., 1999. Evolution of late Campanian-Maastrichtian marine climates and oceans. In: Barrera, E., Johnson, C.C. (Eds.), Evolution of the Cretaceous ocean-climate system. Geological Society of America Special Paper 332, 245-282.

Barrera, E., Savin, S. M., Thomas, E., Jones, C. E., 1997. Evidence for thermohaline-circulation reversals controlled by sea-level change in the latest Cretaceous. Geology 25, $715-718$.

Barron, E. J., 1983. A warm, equable Cretaceous: the nature of the problem. Earth-Science Reviews 19, 305-338.

Barron, E.J., Thompson, S.L., Schneider, S.H., 1981. An ice-free Cretaceous? Results from climate model simulations. Science 212, 501-508.

Berner, R.A., Kothavala, Z., 2001. Geocarb III: A revised model of atmospheric $\mathrm{CO}_{2}$ over Phanerozoic time. American Journal of Science 301, 182-204.

Bice, K. L., Huber, B. T., Norris, R. D., 2003. Extreme polar warmth during the Cretaceous greenhouse? Paradox of the late Turonian $\delta^{18} \mathrm{O}$ record at Deep Sea Drilling Project Site 511. Paleoceanography 18, 1031, doi:10.1029/ 2002PA000848, 2003.

Bornemann, A., Norris, R.D., Friedrich, O., Beckmann, B., Schouten, S., Damsté, J.S.S., Vogel, J., Hofmann, P., Wagner, T., 2008. Isotopic Evidence for Glaciation During the Cretaceous Supergreenhouse. Science 319, 189192.

Browning, J.V., Miller, K.G., Sugarman, P.J., Kominz, M.A., McLaughlin, P.P., Kulpecz, A.A., Feigenson, M.D., 2008. 100 Myr record of sequences, sedimentary facies and sea level change from Ocean Drilling Program onshore coreholes, US Mid-Atlantic coastal plain. Basin Research 20, 227-248.

Chenot, E., Pellenard, P., Martinez, M., Deconinck, J.-F., Amiotte-Suchet, P., Thibault, N., Bruneau, L., Cocquerez, T., Laffont, R., Pucéat, E., Robaszynski, F., 2016. Clay mineral and geochemical expressions of the "Late Campanian Event" in the Aquitaine and Paris basins (France): Palaeoenvironmental implications. Palaeogeography, Palaeoclimatology, Palaeoecology 447, 42-52.
Clarke, L.J., Jenkyns, H.C., 1999. New oxygen isotope evidence for long-term Cretaceous climatic change in the Southern Hemisphere. Geology 27, 699-702.

Coffin, M.F., Pringle, M.S., Duncan, R.A., Gladczenko, T.P., Storey, M., Müller, R.D., Gahagan, L.A., 2002. Kerguelen Hotspot magma output since 130 Ma. Journal of Petrology 43, 1121-1139.

Coffin, M.F., Duncan, R. A., Eldholm, O., Fitton, J. G., Frey, F.A., Larsen, H.C., Mahoney, J.J., Saunders, A.D., Schlich, R., Wallace, P.J., 2006. Large igneous provinces and scientific ocean drilling, status quo and a look ahead. Oceanography 19, 150-160.

Cramer, B.S., Toggweiler, J.R., Wright, J.D., Katz, M.E., Miller, K.G., 2009. Ocean overturning since the Late Cretaceous: Inferences from a new benthic foraminiferal isotope compilation. Paleoceanography, 24, PA4216, doi: 10.1029/2008PA001683.

Donnadieu, Y., Pucéat, E., Moiroud, M., Guillocheau, F., Deconinck, J.-F., 2016. A better-ventilated ocean triggered by Late Cretaceous changes in continental configuration. Nature Communications 7, 10316, doi:10.1038/ ncomms10316.

Falzoni, F., Petrizzo, M.R., Clarke, L.J., MacLeod, K.G., Jenkyns, H.C., 2016. Long-term Late Cretaceous oxygen- and carbon-isotope trends and planktonic foraminiferal turnover: A new record from the southern midlatitudes. GSA Bulletin 128, 1725-1735.

Forster, A., Schouten, S., Baas, M., Sinninghe Damsté, J.S., 2007. Mid-Cretaceous (Albian-Santonian) sea surface temperature record of the tropical Atlantic Ocean. Geology 35, 919-922.

Francis, J.E., Poole, I., 2002. Cretaceous and early Tertiary climates of Antarctica: evidence from fossil wood. Palaeogeography, Palaeoclimatology, Palaeoecology 182, 4764.

Frank, T. D.,Arthur, M. A., 1999. Tectonic forcings of Maastrichtian ocean-climate evolution. Paleoceanography 14, 103-117.

Frey, F. A., Coffin, M. F., Wallace, P.J., Weis, D., Zhao, X., Wise Jr., S.W., Wähnert, V., Teagle, D.A.H., Saccocia, P.J., Reusch, D.N., Pringle, M.S., Nicolaysen, K.E., Neal, C.R., Müller, R.D., Moore, C.L., Mahoney, J.J., Keszthelyi, L., Inokuchi, H., Duncan, R.A., Delius, H., Damuth, J.E., Damasceno, D., Coxall, H.K., Borre, N. K., Boehm, F., Barling, J., Arndt, N. T., Arntretter, M., 2000. Origin and evolution of a submarine large igneous province: the Kerguelen Plateau and Broken Ridge, southern Indian Ocean. Earth and Planetary Science Letters $176,73-89$.

Friedrich, O., Herrle, J. O., Wilson, P. A., Cooper, M. J., Erbacher, J., Hemleben, C., 2009. The early Maastrichtian carbon cycle perturbation and cooling event: Implications from the South Atlantic Ocean. Paleoceanography 24, PA2211. doi:10.1029/2008PA001654.

Friedrich, O., Norris, R.D., Erbacher, J., 2012. Evolution of middle to Late Cretaceous oceans - A 55 m.y. record of Earth's temperature and carbon cycle. Geology 40, 107110. 
Gradstein, F.M., Ogg, J.G., Schmitz, M., Ogg, G., 2012. The Geological Time Scale 2012. Elsevier Science Ltd., Boston, 1144 pp.

Hasegawa, T., Pratt, L. M., Maeda, H., Shigeta, Y., Okamotoe, T., Kased, T., Uemura, K., 2003. Upper Cretaceous stable carbon isotope stratigraphy of terrestrial organic matter from Sakhalin, Russian Far East: a proxy for the isotopic composition of paleoatmospheric $\mathrm{CO}_{2}$. Palaeogeography, Palaeoclimatology, Palaeoecology 189, 97-115.

Hay, W.W., 2008. Evolving ideas about the Cretaceous climate and ocean circulation. Cretaceous Research 29, 725-753.

Hay, W.W., 2011. Can humans force a return to a 'Cretaceous' climate? Sedimentary Geology 235, 5-26.

Hay, W. W., Floegel, S., 2012. New thoughts about the Cretaceous climate and oceans. Earth-Science Reviews 115, 262-272.

Holmden, C., Creaser, R.A., Muehlenbachs, K., Leslie, S. A., Bergström, S. M., 1998. Isotopic evidence for geochemical decoupling between ancient epeiric seas and bordering oceans: Implications for secular curves. Geology 26, 567-570.

Huber, B. T., Hodell, D. A., Hamilton, C. P., 1995. MiddleLate Cretaceous climate of the southern high latitudes: Stable isotopic evidence for minimal equator-to-pole thermal gradients. Geological Society of America Bulletin 107, 1164-1191.

Huber, B. T., Norris, R. D., MacLeod, K. G., 2002. Deep-sea paleotemperature record of extreme warmth during the Cretaceous. Geology 30, 123-126.

Jarvis, I., Mabrouk, A., Moody, R. T. J., de Cabrera, S., 2002. Late Cretaceous (Campanian) carbon isotope events, sealevel change and correlation of the Tethys and Boreal realms. Palaeogeography, Palaeoclimatology, Palaeoecology 188, 215-248.

Jarvis, I., Gale, A.S., Jenkyns, H.C., Pearce, M. A., 2006. Secular variation in Late Cretaceous carbon isotopes: a new $\delta^{13} \mathrm{C}$ carbonate reference curve for the CenomanianCampanian (99.6-70.6 Ma). Geological Magazine 143, 561-608.

Jenkyns, H.C., Gale, A.S., Corfield, R. M., 1994. Carbonand oxygen-isotope stratigraphy of the English Chalk and Italian Scaglia and its palaeoclimatic significance. Geological Magazine 131, 1-34.

Jenkyns, H. C., Forster, A., Schouten, S., Sinninghe Damsté, J.S., 2004. High temperatures in the Late Cretaceous Arctic Ocean. Nature 432, 888-892.

Jung, C., Voigt, S., Friedrich, O., Koch, M.C., Frank, M., 2013. Campanian-Maastrichtian ocean circulation in the tropical Pacific. Paleoceanography 28, 1-12, doi: 10.1002/palo.20051.

Kemp, D.B., Robinson, S.A., Crame, J.A., Francis, J.E., Ineson, J., Whittle, R. J., Vanessa Bowman, V., O'Brien, C., 2014. A cool temperate climate on the Antarctic Peninsula through the latest Cretaceous to early Paleogene. Geology 42, 583-586.

Kidder, D.L., Worsley, T.R., 2012. A human-induced hothouse climate? GSA Today 22 (2), 4-11.
Kump, L.R., Arthur, M.A., 1999. Interpreting carbon-isotope excursions; carbonates and organic matter. Chemical Geology 161, 181-198.

Ladant, J.-B., Donnadieu, Y., 2016. Palaeogeographic regulation of glacial events during the Cretaceous supergreenhouse. Nature Communications 7, 12771, doi:10.1038/ ncomms 12771 .

Larson, R.L., 1991. Latest pulse of Earth: evidence for a mid-Cretaceous superplume. Geology 19, 547-550.

Li, X., Jenkyns, H.C., Wang, C., Hu, X., Chen, X., Wei, Y., Huang, Y., Cui, J., 2006. Upper Cretaceous carbon- and oxygen-isotope stratigraphy of hemipelagic carbonate facies from southern Tibet, China. Journal of the Geological Society, 163, 375-382.

Linnert, C., Robinson, S.A., Lees, J.A., Bown, P.R., Rodríguez, I.P., Petrizzo, M.R., Falzoni, F., Littler, K., Arz, J. A., Russell, E.E., 2014. Evidence for global cooling in the Late Cretaceous. Nature Communications 5, 4194, doi:10.1038/ncomms5194.

MacLeod, K.G., Londoño, C.I., Martin, E.E., Jiménez Berrocoso, Á., Basak, C., 2011. Changes in North Atlantic circulation at the end of the Cretaceous greenhouse interval. Nature Geoscience 4, 779-782.

MacLeod, K.G., Huber, B.T., Jiménez Berrocoso, Á., Wendler, I., 2013. A stable and hot Turonian without glacial $\delta^{18} \mathrm{O}$ excursions is indicated by exquisitely preserved Tanzanian foraminifera. Geology 41, 1083-1086.

Martin, E.E., MacLeod, K.G., Jiménez Berrocoso, Á., Bourbon, E., 2012. Water mass circulation on Demerara Rise during the Late Cretaceous based on Nd isotopes. Earth and Planetary Science Letters 327, 111-120.

Miller, K.G., Barrera, E., Olsson, R.K., Sugarman, P.J., Savin, S.M., 1999. Does ice drive early Maastrichtian eustasy? Geology 27, 783-786.

Miller, K. G., Wright, J. D., Browning, J. V., 2005. Visions of ice sheets in a greenhouse world. Marine Geology 217, 215-231.

Moiroud, M., Pucéat, E., Donnadieu, Y., Bayon, G., Moriya, K., Deconinck, J.F., Boyet, M., 2013. Evolution of the neodymium isotopic signature of neritic seawater on a northwestern Pacific margin: new constrains on possible end-members for the composition of deep-water masses in the Late Cretaceous ocean. Chemical Geology 356, $160-170$.

Moiroud, M., Pucéat, E., Donnadieu, Y., Bayon, G., Guiraud, M., Voigt, S., Deconinck, J. F., Monna, F., 2016. Evolution of neodymium isotopic signature of seawater during the Late Cretaceous: Implications for intermediate and deep circulation. Gondwana Research 36, 503-522.

Müller, R.D., Sdrolias, M., Gaina, C., Roest, W.R., 2008. Age, spreading rates, and spreading asymmetry of the world's ocean crust. Geochemistry, Geophysics, Geosystems 9, Q04006, doi:10.1029/2007GC001743.

Murphy, D.P., Thomas, D.J., 2012. Cretaceous deep-water formation in the Indian sector of the Southern Ocean. Paleoceanography 27, PA1211, doi:10.1029/2011PA002198.

Murphy, D.P., Thomas, D.J., 2013. The evolution of Late Cretaceous deep-ocean circulation in the Atlantic basins: 
Neodymium isotope evidence from South Atlantic drill sites for tectonic controls. Geochemistry, Geophysics, Geosystems 14, 5323-5340, doi:10.1002/2013GC004889.

Pérez-Rodríguez, I., Lees, J. A., Larrasoaña, J.C., Arz, J. A., Arenillas, I., 2012. Planktonic foraminiferal and calcareous nannofossil biostratigraphy and magnetostratigraphy of the uppermost Campanian and Maastrichtian at $\mathrm{Zu}-$ maia, northern Spain. Cretaceous Research 37, 100-126.

Robinson, S.A., Murphy, D.P., Vance, D., Thomas, D.J., 2010. Formation of "Southern Component Water" in the Late Cretaceous: Evidence from Nd-isotopes. Geology $38,871-874$.

Robinson, S. A., Vance, D., 2012. Widespread and synchronous change in deep-ocean circulation in the North and South Atlantic during the Late Cretaceous. Paleoceanography 27, doi:10.1029/2011PA002240.

Sames, B., Wagreich, M., Wendler, J.E., Haq, B. U., Conrad, C.P., Melinte-Dobrinescu, M.C., Hu, X., Wendler, I., Wolfgring, E., Yilmaz, I.Ö., Zorina, S.O., 2016. Shortterm sea-level changes in a greenhouse world $-\mathrm{A}$ view from the Cretaceous. Palaeogeography, Palaeoclimatology, Palaeoecology 441, 393-411.

Sharp, Z., 2006. Principles of Stable Isotope Geochemistry. Prentice Hall, Upper Saddle River, New Jersey, 344 pp.

Sinninghe Damsté, J.S., van Bentum, E.C., Reichart, G.-J., Pross, J., Schouten, S., 2010. A $\mathrm{CO}_{2}$ decrease-driven cooling and increased latitudinal temperature gradient during the mid-Cretaceous Oceanic Anoxic Event 2. Earth and Planetary Science Letters 293,91-103.

Tabor, C.R., Poulsen, C.J., Lunt, D. J., Rosenbloom, N. A., Otto-Bliesner, B. L., Markwick, P. J., Brady, E. C., Farnsworth, A., Feng, R., 2016. The cause of Late Cretaceous cooling: A multi model-proxy Comparison. Geology, doi: $10.1130 / \mathrm{G} 38363.1$

Thibault, N., Harlou, R., Schovsbo, N., Schiøler, P., Minoletti, F., Galbrun, B., Lauridsen, B. W., Sheldon, E., Stemmerik, L., Surlyk, F., 2012a. Upper Campanian-Maastrichtian nannofossil biostratigraphy and high-resolution carbon-isotope stratigraphy of the Danish Basin: Towards a standard $\delta^{13} \mathrm{C}$ curve for the Boreal Realm. Cretaceous Research 33, 72-90.

Thibault, N., Husson, D., Harlou, R., Gardin, S., Galbrun, B., Huret, E., Minoletti, F., 2012b. Astronomical calibration of upper Campanian-Maastrichtian carbon isotope events and calcareous plankton biostratigraphy in the Indian Ocean (ODP Hole 762C): Implication for the age of the Campanian-Maastrichtian boundary. Palaeogeography, Palaeoclimatology, Palaeoecology 337-338, 5271.
Veizer, 1983. Chemical diagenesis of carbonates: theory and application of trace element technique. In: Arthur, M.A., Anderson, T.F., Kaplan, I.R., Veizer, J., Land, L.S. (Eds.), Stable Isotopes in Sedimentary Geology: Society of Economic Paleontologists and Mineralogists Short Course No. 10. Dallas, pp. 3/1-3/10.

Voigt, S., Friedrich, O., Norris, R.D., Schönfeld, J., 2010. Campanian-Maastrichtian carbon isotope stratigraphy: shelf-ocean correlation between the European shelf sea and the tropical Pacific Ocean. Newsletters on Stratigraphy $44,57-72$.

Voigt, S., Gale, A. S., Jung, C., Jenkyns, H.C., 2012. Global correlation of Upper Campanian-Maastrichtian successions using carbon-isotope stratigraphy: development of a new Maastrichtian timescale. Newsletters on Stratigraphy $45,25-53$.

Voigt, S., Jung, C., Friedrich, O., Frank, M., Teschner, C., Hoffmann, J., 2013. Tectonically restricted deep-ocean circulation at the end of the Cretaceous greenhouse. Earth and Planetary Science Letters 369-370, 169-177.

Wagreich, M., Lein, R., Sames, B., 2014. Eustasy, its controlling factors, and the limno-eustatic hypothesis - concepts inspired by Eduard Suess. Journal of Austrian Earth Sciences 107, 115-131

Wendler, I., 2013. A critical evaluation of carbon isotope stratigraphy and biostratigraphic implications for Late Cretaceous global correlation. Earth Science Reviews 126, 116-146.

Wendler, J.E., Wendler, I. 2016. What drove cyclic sea-level fluctuations during the mid-Cretaceous greenhouse climate? Palaeogeography, Palaeoclimatology, Palaeoecology 441, 412-419.

Wendler I., Willems, H., Gräfe, K.-U., Ding, L., Luo, H., 2011. Upper Cretaceous inter-hemispheric correlation between the Southern Tethys and the Boreal: chemo- and biostratigraphy and paleoclimatic reconstructions from a new section in the Tethys Himalaya, S-Tibet. Newsletters on Stratigraphy 44, 137-171.

Wilson, P. A., Norris, R. D., Cooper, M. J., 2002. Testing the Cretaceous greenhouse hypothesis using glassy foraminiferal calcite from the core of the Turonian tropics on Demerara Rise. Geology 30, 607-610.

Zachos, J.C., Dickens, G.R., Zeebe, R.E., 2008. An early Cenozoic perspective on greenhouse warming and carbon-cycle dynamics. Nature 451, 279-283.

Manuscript received: January 4, 2016

Revised version accepted: March 17, 2017 


\section{Appendices}

Supplementary Table 1 Geochemical data from the Shuqualak-Evans core (TOC, $\% \mathrm{CaCO}_{3}, \delta^{13} \mathrm{C}_{\text {carbonate }}, \delta^{18} \mathrm{O}_{\text {carbonate }}$ ).

\begin{tabular}{|c|c|c|c|c|c|c|c|c|c|c|c|c|c|c|c|}
\hline Sample Name & $\begin{array}{l}\text { Depth } \\
\text { (m) }\end{array}$ & $\begin{array}{l}\text { Age } \\
\text { (Ma) } \\
\text { after } \\
\text { Linneert } \\
\text { et al. } \\
2014\end{array}$ & $\begin{array}{l}\text { Age } \\
\text { (Ma) } \\
\text { this } \\
\text { study }\end{array}$ & $\delta^{13} \mathrm{C}$ & $\delta^{18} \mathrm{O}$ & $\begin{array}{l}\mathrm{CaCO}_{3} \\
(\%)\end{array}$ & $\begin{array}{l}\text { TOC } \\
(\%)\end{array}$ & Sample Name & $\begin{array}{l}\text { Depth } \\
\text { (m) }\end{array}$ & $\begin{array}{l}\text { Age } \\
\text { (Ma) } \\
\text { after } \\
\text { Linneert } \\
\text { et al. } \\
2014\end{array}$ & $\begin{array}{l}\text { Age } \\
\text { (Ma) } \\
\text { this } \\
\text { study }\end{array}$ & $\delta^{13} \mathrm{C}$ & $\delta^{18} \mathrm{O}$ & $\begin{array}{l}\mathrm{CaCO}_{3} \\
(\%)\end{array}$ & $\begin{array}{l}\text { TOC } \\
(\%)\end{array}$ \\
\hline SHUQ31 & 9.45 & 65.71 & 65.71 & 0.77 & -2.11 & 69.8 & 0.35 & SHUQ280 & 85.34 & 75.86 & 75.86 & 1.45 & -2.42 & 79.8 & 0.41 \\
\hline SHUQ36 & 10.97 & 66.43 & 66.43 & 0.86 & -2.46 & 85.8 & 0.20 & SHUQ285 & 86.87 & & 75.91 & 1.62 & -2.24 & 82.0 & 0.39 \\
\hline SHUQ42 & 12.80 & 67.30 & 67.30 & 0.96 & -1.94 & 74.9 & 0.37 & HUQ290 & 88.39 & 75.97 & 75.97 & 1.50 & -2.43 & 81.3 & 0.45 \\
\hline SHUQ45 & 13.72 & 67.73 & 67.74 & 0.74 & & 71.5 & & & & & & & & & 0.32 \\
\hline SHUQ50 & 15.24 & 68.46 & 68.46 & 0.21 & -1.71 & 69.8 & 0.31 & 300 & 91.44 & 76.08 & & 1.52 & -2.10 & 74.8 & 0.65 \\
\hline SHUQ55 & 16.76 & 9.18 & 69.18 & 0.85 & -1.84 & 69.4 & 0.39 & 304.5 & 92.81 & & & 1.07 & -1.91 & 79.9 & 0.50 \\
\hline SHUQ60 & 18.29 & 9.91 & 69.50 & 0.93 & -1.34 & 48.4 & 0.42 & HUQ305 & 92.96 & 76.13 & 76.13 & 1.19 & -2.00 & 79.7 & 0.58 \\
\hline SHUQ65 & 19.81 & 0.63 & 69.82 & 1.03 & -1.32 & 56.6 & 0.46 & & 94.49 & 76.19 & 76.19 & 1.13 & -2.05 & & 0.49 \\
\hline SHUQ70 & 21.34 & 71.35 & 70.14 & 0.48 & -1.63 & 73.2 & 0.38 & 15 & 96.01 & & 76.24 & & -1.77 & 81.9 & 0.55 \\
\hline SHUQ75 & 22.86 & 72.08 & 70.46 & 0.89 & -1.57 & 67.4 & 0.36 & & & & & & -2.10 & & 0.29 \\
\hline SHUQ80 & 24.38 & 72.80 & 70.78 & 0.45 & -1.63 & 62.2 & 0.29 & & & & & & -2.17 & & 0.46 \\
\hline SHUQ85 & 25.91 & 73.52 & 71.10 & 1.19 & -1.65 & 38.1 & 0.51 & & 100.58 & 76.41 & 76.41 & 1.23 & -2.26 & 84 & 0.33 \\
\hline SHUQ90 & 27.43 & 73.78 & 71.42 & 0.22 & -1.9 & 24.2 & 0.58 & & 2.11 & 76.46 & 76.46 & 1.49 & -2.01 & 73 & 0.67 \\
\hline SHUQ95 & 28.96 & 73.83 & 71.62 & 0.99 & -1. & & & & & & & & & & 0.41 \\
\hline SHUQ100 & 30.48 & 3.89 & 71.74 & .23 & -2.2 & 51.9 & & & & & & & & & 0.39 \\
\hline SHUQ105 & 32.00 & 3.94 & 71.86 & 0.54 & -2 . & 52.9 & 0.3 & & & & & & & 86.0 & 0.42 \\
\hline SHUQ110 & 33.53 & 74.00 & 71.97 & 1.00 & -1.40 & 44.5 & 0.60 & & & & 76.68 & & -1.94 & 79 & 0.56 \\
\hline SHUQ115 & 35.05 & 74.05 & 72.09 & 0.64 & -2.1 & 55.5 & 0.4 & & 109.73 & 76.73 & 76.73 & 1.40 & -2.38 & 80.2 & 0.59 \\
\hline SHUQ120 & 36.58 & & 72.21 & & -2. & & & & & & & & & & 0.83 \\
\hline SHUQ125 & 38.10 & 74.16 & 72.32 & 1.25 & -1. & 37.1 & 0.5 & & & & & & & 74 & 0.67 \\
\hline SHUQ130 & 39.62 & 74.22 & 72.44 & 0.31 & -2 . & 64.4 & 0.43 & & & & & & & 79 & 0.63 \\
\hline SHUQ135 & 41.15 & 74.27 & 72.56 & 0.95 & -2. & 64.5 & 0.3 & & & 76.95 & & 1.40 & -2.26 & 62 & 1.14 \\
\hline & & & 72.67 & & & & & & & & & & & & \\
\hline & & & & & & & & & & & & & & & \\
\hline SHUQ149 & 45.42 & 74.43 & 72.88 & 1.32 & -1. & 40.0 & 0.6 & & & & & 99 & 43 & 72.1 & 0.57 \\
\hline & 45.72 & & 72.91 & 1.38 & -2 & 47.9 & & & & & & & & 72 & 0.86 \\
\hline SHUQ154 & 46.94 & 74.48 & 73.00 & 1.38 & -1.48 & 46.5 & & & 28.02 & 77.39 & 77.39 & 1.2 & -2.42 & 67.3 & 0.94 \\
\hline & & & & & & & & & & & & & & 77.1 & \\
\hline & & & & & & & & & & & & & & & 0.69 \\
\hline SHUQ165 & 50.29 & 74.60 & 73.26 & 1.21 & -1.5 & 73.1 & 0.3 & & 2.59 & 77.55 & 77.55 & 10 & -2 & 74.6 & 0.56 \\
\hline SHUQ170 & 51.82 & 74.66 & 73.37 & 1.08 & -1.7 & 80.6 & 0.28 & & & 77.61 & 77.61 & 1.11 & & 69 & 0.53 \\
\hline SHUQ175 & 53.34 & 4.71 & 73.49 & 1.31 & -1.99 & 86.2 & 0.21 & & & & 77.66 & 1.18 & -2.43 & 68.4 & 0.72 \\
\hline SHUQ180 & & & & & & & & & & & & & & 63.5 & 0.62 \\
\hline & & 74.82 & & & & & & & & & & & & & 0.93 \\
\hline SHUQ190 & 57.91 & 74.87 & 73.84 & 1.30 & -1.75 & 84.0 & 0.24 & & 140.21 & 77.83 & 77.83 & 1.70 & -2.40 & 49.1 & 1.36 \\
\hline SHUQ195 & 59.44 & 74.93 & 73.96 & 1.39 & -1.69 & 89.6 & 0.20 & & 141.73 & 77.88 & 77.88 & 1.61 & -2.43 & 51.7 & 1.28 \\
\hline SHUQ200 & 60.96 & 74.98 & 74.07 & 1.41 & -1.93 & 86.9 & 0.21 & & & 77.94 & 77.94 & 1.52 & -2.48 & 66.5 & 1.05 \\
\hline & 62.48 & & 74.19 & & & 80.4 & & & & & & & & 70 & 0.81 \\
\hline SHUQ210 & 64.01 & 75.09 & 74.31 & 1.30 & -2.19 & 80.4 & 0.28 & & 146.30 & 78.05 & 78.05 & 1.71 & -2.19 & 62.4 & 1.18 \\
\hline SHUQ215 & 65.53 & 75.15 & 74.42 & 1.41 & -1.87 & 86.2 & 0.19 & & 147.83 & 78.10 & 78.10 & 1.13 & -2.77 & 72.4 & 0.63 \\
\hline SHUQ220 & 67.06 & 75.20 & 74.54 & 1.44 & -1.95 & 90.3 & 0.18 & & 149.35 & 78.16 & 78.16 & 1.93 & -2.47 & 48.7 & 0.91 \\
\hline SHUQ225 & 68.58 & 75.26 & 74.66 & 1.53 & -1.83 & 85.0 & 0.24 & & 150.88 & 78.21 & 78.21 & 1.31 & -2.67 & 72.9 & 0.57 \\
\hline & 70.10 & 75.31 & 74.78 & 1.50 & & 81.9 & & & & & 78.27 & & & 73.9 & 0.95 \\
\hline SHUQ235 & 71.63 & 75.37 & 74.89 & 1.39 & -2.02 & 82.8 & 0.37 & & 153.92 & 78.32 & 78.32 & 1.49 & -2.73 & 58.6 & 0.73 \\
\hline SHUQ240 & 73.15 & 75.42 & 75.01 & 1.45 & -2.42 & 82.3 & 0.39 & HUQ510 & 155.45 & 78.38 & 78.38 & 1.27 & -2.87 & 76.9 & 0.61 \\
\hline SHUQ245 & 74.68 & 75.48 & 75.13 & 1.45 & -2.43 & 79.9 & 0.32 & HUQ515 & 156.97 & 78.43 & 78.43 & 1.66 & -2.60 & 55.3 & 1.51 \\
\hline & 76.20 & 75.53 & 75.24 & 1.46 & -2.46 & 79.0 & 0.3 & & 158.50 & 78.49 & 78.49 & 1.30 & -2.76 & 69.7 & 0.75 \\
\hline & 77.72 & & 75.36 & 1.55 & -2.69 & 81.8 & & & & & & & & 65.6 & 0.75 \\
\hline SHUQ260 & 79.25 & 75.64 & 75.48 & 1.50 & -2.73 & 78.3 & 0.41 & SHUQ530 & 161.54 & 78.59 & 78.59 & 1.54 & -2.50 & 60.8 & 1.29 \\
\hline SHUQ265 & 80.77 & 75.69 & 75.59 & 1.72 & -2.39 & 71.2 & 0.48 & SHUQ535 & 163.07 & 78.65 & 78.65 & 1.47 & -2.38 & 55.2 & 1.26 \\
\hline & 82.30 & 75.75 & 75.71 & 1.71 & -2.46 & 67.1 & 0.46 & & 164.59 & 78.70 & 78.70 & 1.01 & -2.75 & 60.7 & 1.05 \\
\hline SHUQ275 & 83.82 & 75.80 & 75.80 & 1.32 & -2.36 & 81.9 & 0.39 & SHUQ545 & 166.12 & 78.76 & 78.76 & 0.97 & -2.40 & 64.4 & 0.91 \\
\hline
\end{tabular}


C. Linnert et al.

\begin{tabular}{|c|c|c|c|c|c|c|c|}
\hline Sample Name & $\begin{array}{l}\text { Depth } \\
\text { (m) }\end{array}$ & $\begin{array}{l}\text { Age } \\
(\mathrm{Ma}) \\
\text { after } \\
\text { Linneert } \\
\text { et al. } \\
2014\end{array}$ & $\begin{array}{l}\text { Age } \\
\text { (Ma) } \\
\text { this } \\
\text { study }\end{array}$ & $\delta^{13} \mathrm{C}$ & $\delta^{18} \mathrm{O}$ & $\begin{array}{l}\mathrm{CaCO}_{3} \\
(\%)\end{array}$ & $\begin{array}{l}\text { TOC } \\
(\%)\end{array}$ \\
\hline SHUQ550 & 167.64 & 78.81 & 78.81 & 1.19 & -3.20 & 62.3 & 1.15 \\
\hline SHUQ555 & 169.16 & 78.87 & 78.87 & 1.06 & -3.53 & 67.3 & 0.86 \\
\hline SHUQ560 & 170.69 & 78.92 & 78.92 & 1.65 & -2.33 & 43.6 & 1.41 \\
\hline SHUQ565 & 172.21 & 78.98 & 78.98 & 1.39 & -3.17 & 56.9 & 1.04 \\
\hline SHUQ570 & 173.74 & 79.03 & 79.03 & 1.32 & -2.69 & 60.2 & 0.71 \\
\hline SHUQ575 & 175.26 & 79.09 & 79.09 & 1.84 & -2.86 & 86.8 & 0.57 \\
\hline SHUQ580 & 176.78 & 79.14 & 79.14 & 1.66 & -2.80 & 67.6 & 0.47 \\
\hline SHUQ585 & 178.31 & 79.20 & 79.20 & 0.66 & -2.63 & 66.6 & 0.40 \\
\hline SHUQ590 & 179.83 & 79.25 & 79.25 & 1.50 & -2.78 & 56.1 & 0.81 \\
\hline SHUQ595 & 181.36 & 79.31 & 79.31 & 1.40 & -2.74 & 43.8 & 1.06 \\
\hline SHUQ600 & 182.88 & 79.36 & 79.36 & 1.45 & -3.07 & 59.2 & 0.89 \\
\hline SHUQ605 & 184.40 & 79.42 & 79.42 & 1.26 & -2.76 & 72.3 & 0.87 \\
\hline SHUQ610 & 185.93 & 79.47 & 79.47 & 1.31 & -3.12 & 51.8 & 1.08 \\
\hline SHUQ615 & 187.45 & 79.52 & 79.52 & 0.84 & -2.65 & 53.6 & 1.00 \\
\hline SHUQ630 & 192.02 & 79.69 & 79.69 & 1.03 & -3.21 & 48.7 & 1.17 \\
\hline SHUQ633 & 192.94 & 79.72 & 79.72 & n.a. & n.a. & 0.0 & 0.17 \\
\hline SHUQ635 & 193.55 & 79.74 & 79.74 & 1.03 & -3.19 & 56.8 & 1.17 \\
\hline SHUQ640 & 195.07 & 79.80 & 79.80 & 0.85 & -2.82 & 54.7 & 1.50 \\
\hline SHUQ645 & 196.60 & 79.85 & 79.85 & 1.38 & -3.07 & 62.4 & 1.17 \\
\hline SHUQ650 & 198.12 & 79.91 & 79.91 & 0.65 & -2.74 & 61.2 & 0.63 \\
\hline SHUQ655 & 199.64 & 79.96 & 79.96 & 1.08 & -2.87 & 58.3 & 0.76 \\
\hline SHUQ660 & 201.17 & 80.02 & 80.02 & 0.84 & -3.02 & 56.3 & 1.46 \\
\hline SHUQ665 & 202.69 & 80.07 & 80.07 & 1.44 & -2.92 & 61.1 & 1.05 \\
\hline SHUQ670 & 204.22 & 80.13 & 80.13 & 0.93 & -2.56 & 61.9 & 1.09 \\
\hline SHUQ675 & 205.74 & 80.18 & 80.18 & 0.78 & -2.80 & 63.2 & 0.75 \\
\hline SHUQ680 & 207.26 & 80.24 & 80.24 & 0.95 & -3.06 & 65.8 & 1.50 \\
\hline SHUQ685 & 208.79 & 80.29 & 80.29 & 1.12 & -3.20 & 68.2 & 1.17 \\
\hline SHUQ690 & 210.31 & 80.35 & 80.35 & 0.89 & -3.03 & 61.9 & 1.45 \\
\hline
\end{tabular}

\begin{tabular}{|c|c|c|c|c|c|c|c|}
\hline Sample Name & $\begin{array}{l}\text { Depth } \\
\text { (m) }\end{array}$ & $\begin{array}{l}\text { Age } \\
\text { (Ma) } \\
\text { after } \\
\text { Linneert } \\
\text { et al. } \\
2014\end{array}$ & $\begin{array}{l}\text { Age } \\
\text { (Ma) } \\
\text { this } \\
\text { study }\end{array}$ & $\delta^{13} \mathrm{C}$ & $\delta^{18} \mathrm{O}$ & $\begin{array}{l}\mathrm{CaCO}_{3} \\
(\%)\end{array}$ & $\begin{array}{l}\text { TOC } \\
(\%)\end{array}$ \\
\hline SHUQ695 & 211.84 & 80.40 & 80.40 & 0.54 & -3.05 & 75.7 & 0.50 \\
\hline SHUQ700 & 213.36 & 80.45 & 80.45 & 0.87 & -2.82 & 67.7 & 1.02 \\
\hline SHUQ705 & 214.88 & 80.51 & 80.51 & 1.01 & -3.56 & 58.3 & 1.43 \\
\hline SHUQ710 & 216.41 & 80.56 & 80.56 & 1.30 & -3.08 & 54.3 & 1.49 \\
\hline SHUQ715 & 217.93 & 80.62 & 80.62 & 1.32 & -3.08 & 60.4 & 0.99 \\
\hline SHUQ720 & 219.46 & 80.67 & 80.67 & 0.85 & -2.68 & 69.1 & 0.91 \\
\hline SHUQ725 & 220.98 & 80.73 & 80.73 & 1.33 & -3.41 & 43.1 & 0.51 \\
\hline SHUQ740 & 225.55 & 80.89 & 80.89 & 1.25 & -2.92 & 67.3 & 1.05 \\
\hline SHUQ745 & 227.08 & 80.95 & 80.95 & 1.28 & -3.27 & 70.6 & 1.10 \\
\hline SHUQ750 & 228.60 & 81.00 & 81.00 & 1.16 & -3.31 & 67.0 & 1.24 \\
\hline SHUQ755 & 230.12 & 81.06 & 81.06 & 0.86 & -2.96 & 69.5 & 0.73 \\
\hline SHUQ760 & 231.65 & 81.11 & 81.11 & 0.89 & -3.63 & 68.1 & 1.16 \\
\hline SHUQ765 & 233.17 & 81.17 & 81.17 & 1.17 & -3.65 & 69.1 & 1.02 \\
\hline SHUQ770 & 234.70 & 81.22 & 81.22 & 0.98 & -3.63 & 74.1 & 1.02 \\
\hline SHUQ775 & 236.22 & 81.28 & 81.28 & 0.95 & -3.19 & 66.7 & 1.10 \\
\hline SHUQ780 & 237.74 & 81.33 & 81.33 & 1.53 & -3.05 & 56.7 & 0.59 \\
\hline SHUQ785 & 239.27 & 81.38 & 81.38 & 1.09 & -2.98 & 79.8 & 0.53 \\
\hline SHUQ790 & 240.79 & 81.44 & 81.44 & 0.95 & -2.96 & 68.0 & 0.81 \\
\hline SHUQ795 & 242.32 & 81.49 & 81.49 & 0.95 & -3.64 & 71.1 & 0.62 \\
\hline SHUQ800 & 243.84 & 81.55 & 81.55 & 1.18 & -2.77 & 54.1 & 0.92 \\
\hline SHUQ805 & 245.36 & 81.60 & 81.60 & 1.25 & -3.22 & 65.2 & 0.79 \\
\hline SHUQ810 & 246.89 & 81.66 & 81.66 & 1.05 & -3.24 & 64.6 & 0.83 \\
\hline SHUQ815 & 248.41 & 81.71 & 81.71 & 1.67 & -3.36 & 26.9 & 0.41 \\
\hline SHUQ820 & 249.94 & 82.00 & 81.77 & 1.41 & -2.99 & 38.5 & 0.69 \\
\hline SHUQ825 & 251.46 & 82.56 & 83.02 & 1.10 & -3.28 & 43.6 & 0.50 \\
\hline SHUQ826.67 & 251.97 & 82.75 & 83.20 & n.a. & n.a. & 31.7 & 0.69 \\
\hline SHUQ829.5 & 252.83 & 83.07 & 83.51 & -1.42 & -5.82 & 16.2 & 0.36 \\
\hline SHUQ830.67 & 253.19 & 83.20 & 83.64 & n.a. & n.a. & 0.4 & 0.28 \\
\hline
\end{tabular}


Supplementary Table 2 Stable-isotope data $\left(\delta^{13} \mathrm{C}_{\text {carbonate }}, \delta^{18} \mathrm{O}_{\text {carbonate }}\right)$ from the Trunch core.

\begin{tabular}{|c|c|c|c|c|c|c|c|c|c|c|c|}
\hline $\begin{array}{l}\text { Depth } \\
\text { (m) }\end{array}$ & $\begin{array}{l}\text { Age } \\
(\mathrm{Ma})\end{array}$ & $\delta^{13} \mathrm{C}$ & $\delta^{18} \mathrm{O}$ & $\begin{array}{l}\text { Depth } \\
\text { (m) }\end{array}$ & $\begin{array}{l}\text { Age } \\
(\mathrm{Ma})\end{array}$ & $\delta^{13} \mathrm{C}$ & $\delta^{18} \mathrm{O}$ & $\begin{array}{l}\text { Depth } \\
\text { (m) }\end{array}$ & $\begin{array}{l}\text { Age } \\
(\mathrm{Ma})\end{array}$ & $\delta^{13} \mathrm{C}$ & $\delta^{18} \mathrm{O}$ \\
\hline 47.17 & 72.45 & 1.68 & -1.77 & 101.60 & 74.43 & 1.98 & -1.84 & 111.00 & 75.02 & 1.95 & -1.75 \\
\hline 48.10 & 72.47 & 1.68 & -1.89 & 101.70 & 74.44 & 2.03 & -1.84 & 111.07 & 75.02 & 2.02 & -1.94 \\
\hline 49.00 & 72.50 & 1.76 & -1.77 & 101.80 & 74.45 & 2.09 & -1.96 & 111.10 & 75.03 & 1.95 & -1.68 \\
\hline 49.78 & 72.52 & 1.72 & -1.77 & 102.00 & 74.46 & 2.10 & -1.64 & 111.20 & 75.03 & 1.98 & -1.76 \\
\hline 58.00 & 72.75 & 1.89 & -2.31 & 102.10 & 74.47 & 2.08 & -1.76 & 111.31 & 75.04 & 1.94 & -1.98 \\
\hline 58.98 & 72.77 & 1.95 & -2.03 & 102.11 & 74.47 & 1.91 & -1.87 & 111.40 & 75.04 & 1.97 & -2.05 \\
\hline 60.10 & 72.80 & 1.99 & -2.11 & 102.20 & 74.47 & 2.01 & -1.83 & 111.50 & 75.05 & 2.01 & -1.81 \\
\hline 61.00 & 72.83 & 1.93 & -1.99 & 102.30 & 74.48 & 2.04 & -1.84 & 111.60 & 75.06 & 1.92 & -1.95 \\
\hline 62.53 & 72.87 & 2.04 & -2.02 & 102.40 & 74.48 & 1.97 & -1.87 & 111.70 & 75.06 & 1.97 & -1.81 \\
\hline 64.00 & 72.92 & 1.92 & -2.08 & 102.50 & 74.49 & 2.18 & -1.13 & 111.80 & 75.07 & 1.95 & -1.51 \\
\hline 67.51 & 73.08 & 1.93 & -2.27 & 102.60 & 74.50 & 2.07 & -1.65 & 111.86 & 75.07 & 1.96 & -1.62 \\
\hline 71.13 & 73.25 & 2.00 & -1.81 & 102.70 & 74.50 & 1.97 & -1.77 & 111.90 & 75.08 & 1.97 & -1.84 \\
\hline 80.45 & 73.56 & 1.90 & -2.43 & 102.80 & 74.51 & 1.93 & -1.85 & 112.00 & 75.08 & 2.03 & -1.73 \\
\hline 81.10 & 73.57 & 1.99 & -2.35 & 103.00 & 74.52 & 2.03 & -1.71 & 112.10 & 75.09 & 1.95 & -1.70 \\
\hline 82.28 & 73.61 & 1.89 & -1.89 & 103.01 & 74.52 & 2.04 & -1.71 & 112.20 & 75.09 & 1.95 & -1.74 \\
\hline 83.11 & 73.63 & 1.94 & -2.16 & 103.10 & 74.53 & 2.01 & -1.86 & 112.20 & 75.09 & 1.91 & -1.88 \\
\hline 84.00 & 73.65 & 2.03 & -1.90 & 103.20 & 74.53 & 2.08 & -1.68 & 112.30 & 75.10 & 1.91 & -1.78 \\
\hline 85.15 & 73.68 & 2.07 & -1.87 & 104.01 & 74.58 & 2.06 & -1.86 & 112.40 & 75.11 & 1.98 & -1.70 \\
\hline 86.35 & 73.71 & 1.99 & -1.94 & 104.10 & 74.59 & 2.06 & -1.65 & 112.50 & 75.11 & 1.98 & -1.56 \\
\hline 87.15 & 73.74 & 2.09 & -2.00 & 104.20 & 74.60 & 2.10 & -1.69 & 112.60 & 75.12 & 2.00 & -1.65 \\
\hline 88.12 & 73.76 & 2.15 & -1.98 & 104.20 & 74.60 & 2.08 & -1.70 & 112.70 & 75.13 & 2.01 & -1.73 \\
\hline 89.59 & 73.80 & 2.09 & -1.95 & 104.30 & 74.60 & 2.04 & -1.85 & 112.80 & 75.13 & 1.98 & -1.65 \\
\hline 90.33 & 73.82 & 2.15 & -1.89 & 104.40 & 74.61 & 1.95 & -1.76 & 112.90 & 75.14 & 2.02 & -1.66 \\
\hline 90.85 & 73.84 & 2.04 & -1.81 & 104.50 & 74.62 & 1.97 & -1.78 & 113.00 & 75.14 & 2.03 & -1.54 \\
\hline 92.20 & 73.88 & 2.04 & -1.88 & 104.60 & 74.62 & 2.00 & -1.79 & 113.10 & 75.15 & 1.98 & -1.62 \\
\hline 93.10 & 73.93 & 1.94 & -1.69 & 105.63 & 74.69 & 1.88 & -2.02 & 113.20 & 75.16 & 2.00 & -1.79 \\
\hline 94.40 & 74.00 & 2.13 & -1.79 & 105.70 & 74.69 & 2.04 & -1.87 & 113.28 & 75.16 & 1.97 & -1.60 \\
\hline 95.12 & 74.03 & 2.02 & -1.95 & 106.00 & 74.71 & 1.98 & -1.71 & 113.30 & 75.16 & 1.96 & -1.53 \\
\hline 96.00 & 74.09 & 2.03 & -1.97 & 106.20 & 74.72 & 2.03 & -1.98 & 113.40 & 75.17 & 1.96 & -1.62 \\
\hline 97.05 & 74.15 & 2.13 & -1.77 & 106.30 & 74.73 & 1.92 & -1.64 & 113.50 & 75.18 & 1.94 & -1.71 \\
\hline 98.25 & 74.23 & 2.09 & -1.83 & 106.60 & 74.75 & 2.03 & -1.73 & 113.60 & 75.18 & 1.96 & -1.80 \\
\hline 99.20 & 74.29 & 2.15 & -1.85 & 106.70 & 74.75 & 2.02 & -1.77 & 113.70 & 75.19 & 1.98 & -1.82 \\
\hline 99.28 & 74.29 & 2.02 & -1.78 & 106.80 & 74.76 & 2.07 & -1.79 & 113.79 & 75.19 & 1.88 & -1.84 \\
\hline 99.30 & 74.29 & 2.07 & -1.79 & 108.40 & 74.86 & 2.05 & -1.79 & 113.90 & 75.20 & 1.93 & -1.79 \\
\hline 99.40 & 74.30 & 2.04 & -1.92 & 108.84 & 74.89 & 1.88 & -1.97 & 114.05 & 75.21 & 1.94 & -1.74 \\
\hline 99.50 & 74.30 & 2.08 & -1.87 & 108.91 & 74.89 & 1.90 & -1.96 & 114.10 & 75.21 & 1.97 & -1.74 \\
\hline 99.60 & 74.31 & 1.99 & -1.75 & 109.00 & 74.90 & 1.85 & -1.72 & 114.20 & 75.22 & 1.99 & -1.71 \\
\hline 99.70 & 74.32 & 2.09 & -1.34 & 109.09 & 74.90 & 1.87 & -1.88 & 114.30 & 75.22 & 1.98 & -1.85 \\
\hline 99.80 & 74.32 & 2.00 & -1.88 & 109.10 & 74.90 & 1.90 & -1.79 & 114.39 & 75.23 & 1.94 & -1.76 \\
\hline 99.90 & 74.33 & 2.01 & -1.55 & 109.20 & 74.91 & 1.87 & -1.74 & 114.50 & 75.24 & 1.87 & -1.79 \\
\hline 100.00 & 74.33 & 2.05 & -1.36 & 109.30 & 74.91 & 1.90 & -1.79 & 114.60 & 75.24 & 1.97 & -1.64 \\
\hline 100.10 & 74.34 & 2.07 & -1.86 & 109.40 & 74.92 & 1.98 & -1.74 & 114.70 & 75.25 & 1.95 & -1.74 \\
\hline 100.20 & 74.35 & 2.07 & -1.67 & 109.50 & 74.93 & 1.91 & -1.61 & 114.80 & 75.26 & 1.90 & -1.75 \\
\hline 100.20 & 74.35 & 2.03 & -1.76 & 109.60 & 74.93 & 2.05 & -1.92 & 114.90 & 75.26 & 1.93 & -1.84 \\
\hline 100.30 & 74.35 & 2.07 & -1.83 & 109.70 & 74.94 & 2.03 & -2.05 & 115.06 & 75.27 & 2.01 & -1.60 \\
\hline 100.40 & 74.36 & 2.08 & -1.79 & 109.80 & 74.94 & 2.05 & -2.00 & 115.10 & 75.27 & 1.89 & -1.77 \\
\hline 100.50 & 74.37 & 2.06 & -1.67 & 109.90 & 74.95 & 2.08 & -1.98 & 115.20 & 75.28 & 1.89 & -1.53 \\
\hline 100.60 & 74.37 & 2.06 & -1.82 & 110.00 & 74.96 & 2.08 & -1.88 & 115.30 & 75.29 & 1.83 & -1.82 \\
\hline 100.70 & 74.38 & 2.04 & -1.84 & 110.00 & 74.96 & 2.03 & -1.72 & 115.40 & 75.29 & 1.87 & -1.93 \\
\hline 100.80 & 74.38 & 2.05 & -1.87 & 110.10 & 74.96 & 2.10 & -1.77 & 115.50 & 75.30 & 1.85 & -2.11 \\
\hline 100.90 & 74.39 & 2.11 & -1.74 & 110.20 & 74.97 & 2.02 & -1.80 & 115.60 & 75.31 & 1.82 & -1.64 \\
\hline 101.00 & 74.40 & 2.12 & -1.77 & 110.30 & 74.98 & 2.05 & -1.90 & 115.70 & 75.31 & 1.76 & -1.99 \\
\hline 101.10 & 74.40 & 1.99 & -1.91 & 110.40 & 74.98 & 2.01 & -1.80 & 115.80 & 75.32 & 1.76 & -1.99 \\
\hline 101.10 & 74.40 & 2.03 & -1.62 & 110.50 & 74.99 & 1.96 & -1.73 & 115.90 & 75.32 & 1.73 & -1.97 \\
\hline 101.20 & 74.41 & 2.11 & -1.68 & 110.60 & 74.99 & 1.98 & -1.63 & 116.10 & 75.34 & 1.79 & -1.91 \\
\hline 101.30 & 74.42 & 2.05 & -1.74 & 110.70 & 75.00 & 2.04 & -1.62 & 116.20 & 75.34 & 1.79 & -2.00 \\
\hline 101.40 & 74.42 & 1.95 & -1.84 & 110.80 & 75.01 & 2.01 & -1.65 & 116.25 & 75.35 & 1.75 & -2.04 \\
\hline 101.50 & 74.43 & 2.03 & -1.65 & 110.90 & 75.01 & 1.94 & -1.90 & 116.30 & 75.35 & 1.78 & -2.09 \\
\hline
\end{tabular}


C. Linnert et al.

\begin{tabular}{|c|c|c|c|c|c|c|c|c|c|c|c|}
\hline $\begin{array}{l}\text { Depth } \\
\text { (m) }\end{array}$ & $\begin{array}{l}\text { Age } \\
\text { (Ma) }\end{array}$ & $\delta^{13} \mathrm{C}$ & $\delta^{18} \mathrm{O}$ & $\begin{array}{l}\text { Depth } \\
\text { (m) }\end{array}$ & $\begin{array}{l}\text { Age } \\
\text { (Ma) }\end{array}$ & $\delta^{13} \mathrm{C}$ & $\delta^{18} \mathrm{O}$ & $\begin{array}{l}\text { Depth } \\
\text { (m) }\end{array}$ & $\begin{array}{l}\text { Age } \\
\text { (Ma) }\end{array}$ & $\delta^{13} \mathrm{C}$ & $\delta^{18} \mathrm{O}$ \\
\hline 116.40 & 75.36 & 1.79 & -2.13 & 129.50 & 75.81 & 1.93 & -1.62 & 136.60 & 76.04 & 1.94 & -1.78 \\
\hline 116.50 & 75.36 & 1.81 & -1.86 & 129.60 & 75.81 & 2.00 & -1.87 & 136.70 & 76.04 & 2.03 & -1.83 \\
\hline 116.60 & 75.37 & 1.78 & -1.90 & 129.70 & 75.81 & 1.98 & -1.78 & 136.80 & 76.04 & 1.95 & -1.84 \\
\hline 116.70 & 75.37 & 1.88 & -1.99 & 129.80 & 75.82 & 2.05 & -1.36 & 136.90 & 76.05 & 1.94 & -2.34 \\
\hline 116.80 & 75.38 & 1.78 & -2.03 & 129.90 & 75.82 & 1.98 & -1.71 & 137.00 & 76.05 & 1.98 & -1.87 \\
\hline 116.90 & 75.39 & 1.69 & -1.74 & 130.00 & 75.82 & 1.88 & -1.69 & 137.00 & 76.05 & 2.02 & -1.77 \\
\hline 117.00 & 75.39 & 1.83 & -1.78 & 130.10 & 75.83 & 1.87 & -1.87 & 137.10 & 76.05 & 2.01 & -1.74 \\
\hline 122.20 & 75.56 & 1.63 & -1.84 & 130.10 & 75.83 & 1.95 & -1.87 & 137.20 & 76.06 & 1.92 & -1.82 \\
\hline 122.45 & 75.57 & 1.73 & -1.82 & 130.20 & 75.83 & 1.92 & -1.76 & 137.30 & 76.06 & 1.91 & -1.77 \\
\hline 122.45 & 75.57 & 1.46 & -2.02 & 130.30 & 75.83 & 1.99 & -1.73 & 137.40 & 76.06 & 1.97 & -1.64 \\
\hline 124.00 & 75.62 & 1.41 & -1.73 & 130.40 & 75.84 & 1.98 & -1.86 & 137.50 & 76.07 & 2.04 & -1.91 \\
\hline 124.10 & 75.63 & 1.52 & -2.04 & 130.50 & 75.84 & 1.96 & -1.63 & 137.60 & 76.07 & 2.04 & -2.01 \\
\hline 124.26 & 75.63 & 1.59 & -1.83 & 130.60 & 75.84 & 2.00 & -1.66 & 137.70 & 76.07 & 1.93 & -2.02 \\
\hline 124.40 & 75.64 & 1.65 & -2.38 & 130.70 & 75.85 & 2.02 & -1.81 & 137.80 & 76.08 & 2.08 & -1.73 \\
\hline 124.42 & 75.64 & 1.59 & -1.96 & 130.80 & 75.85 & 2.03 & -2.01 & 137.90 & 76.08 & 2.04 & -2.09 \\
\hline 124.50 & 75.64 & 1.67 & -1.94 & 130.90 & 75.85 & 2.01 & -2.09 & 138.00 & 76.09 & 2.15 & -1.94 \\
\hline 124.60 & 75.64 & 1.68 & -1.72 & 131.02 & 75.86 & 2.00 & -1.63 & 138.10 & 76.09 & 2.10 & -1.89 \\
\hline 124.70 & 75.65 & 1.66 & -1.92 & 131.06 & 75.86 & 1.93 & -1.84 & 138.20 & 76.09 & 2.01 & -2.01 \\
\hline 124.80 & 75.65 & 1.77 & -2.03 & 131.20 & 75.86 & 2.02 & -1.75 & 138.30 & 76.10 & 2.06 & -1.83 \\
\hline 124.90 & 75.65 & 1.71 & -2.12 & 131.30 & 75.87 & 2.01 & -1.79 & 138.40 & 76.10 & 2.25 & -1.38 \\
\hline 125.00 & 75.66 & 1.60 & -2.18 & 131.40 & 75.87 & 2.03 & -1.91 & 138.50 & 76.10 & 2.12 & -1.49 \\
\hline 125.00 & 75.66 & 1.74 & -2.03 & 131.50 & 75.87 & 2.02 & -1.85 & 138.60 & 76.11 & 2.16 & -1.94 \\
\hline 125.10 & 75.66 & 1.69 & -2.19 & 131.60 & 75.88 & 2.09 & -1.81 & 138.70 & 76.11 & 2.22 & -1.90 \\
\hline 125.20 & 75.66 & 1.76 & -1.75 & 131.70 & 75.88 & 2.03 & -1.80 & 138.80 & 76.11 & 2.11 & -2.34 \\
\hline 125.30 & 75.67 & 1.64 & -1.74 & 131.80 & 75.88 & 2.06 & -1.80 & 138.90 & 76.12 & 2.15 & -1.81 \\
\hline 125.40 & 75.67 & 1.87 & -1.78 & 131.90 & 75.89 & 1.99 & -1.88 & 139.40 & 76.13 & 2.22 & -1.89 \\
\hline 125.60 & 75.68 & 1.91 & -1.89 & 132.00 & 75.89 & 2.10 & -1.77 & 139.50 & 76.14 & 2.12 & -1.78 \\
\hline 125.70 & 75.68 & 1.89 & -1.95 & 132.00 & 75.89 & 2.03 & -2.00 & 139.60 & 76.14 & 2.05 & -1.85 \\
\hline 125.80 & 75.68 & 1.89 & -2.26 & 132.10 & 75.89 & 1.99 & -1.82 & 139.70 & 76.14 & 2.02 & -1.88 \\
\hline 125.90 & 75.69 & 1.84 & -2.25 & 132.20 & 75.90 & 2.08 & -1.74 & 139.80 & 76.15 & 2.07 & -1.85 \\
\hline 126.00 & 75.69 & 1.59 & -2.08 & 132.30 & 75.90 & 2.06 & -1.73 & 139.90 & 76.15 & 2.08 & -1.62 \\
\hline 126.00 & 75.69 & 1.91 & -2.26 & 132.40 & 75.90 & 2.10 & -1.82 & 140.00 & 76.16 & 2.08 & -1.72 \\
\hline 126.10 & 75.69 & 1.94 & -1.67 & 132.50 & 75.91 & 2.06 & -1.83 & 140.10 & 76.16 & 2.08 & -1.64 \\
\hline 126.20 & 75.70 & 1.86 & -1.79 & 132.60 & 75.91 & 2.07 & -1.91 & 140.20 & 76.16 & 2.09 & -1.68 \\
\hline 126.30 & 75.70 & 1.85 & -1.82 & 132.70 & 75.91 & 2.08 & -1.63 & 140.30 & 76.17 & 2.09 & -1.61 \\
\hline 126.40 & 75.70 & 1.94 & -1.84 & 132.74 & 75.91 & 2.09 & -1.73 & 140.40 & 76.17 & 2.10 & -1.58 \\
\hline 126.50 & 75.71 & 1.93 & -1.79 & 133.20 & 75.93 & 2.08 & -1.62 & 140.50 & 76.17 & 2.10 & -1.73 \\
\hline 126.60 & 75.71 & 1.92 & -1.98 & 133.25 & 75.93 & 2.05 & -1.83 & 140.60 & 76.18 & 2.08 & -1.81 \\
\hline 126.70 & 75.71 & 1.82 & -1.85 & 133.30 & 75.93 & 2.08 & -1.66 & 140.70 & 76.18 & 2.09 & -1.69 \\
\hline 126.80 & 75.72 & 1.76 & -1.96 & 133.40 & 75.94 & 2.14 & -1.62 & 140.80 & 76.18 & 2.14 & -1.70 \\
\hline 126.90 & 75.72 & 1.96 & -0.92 & 133.50 & 75.94 & 2.10 & -1.61 & 140.90 & 76.19 & 2.16 & -1.67 \\
\hline 127.00 & 75.72 & 1.78 & -1.75 & 133.60 & 75.94 & 2.04 & -1.67 & 141.00 & 76.19 & 2.25 & -1.87 \\
\hline 127.05 & 75.73 & 1.76 & -1.69 & 133.70 & 75.95 & 1.97 & -1.89 & 141.00 & 76.19 & 2.12 & -1.75 \\
\hline 127.10 & 75.73 & 1.71 & -1.92 & 133.80 & 75.95 & 2.04 & -1.67 & 141.10 & 76.19 & 2.07 & -1.77 \\
\hline 127.20 & 75.73 & 1.82 & -1.74 & 133.90 & 75.95 & 2.01 & -1.88 & 141.20 & 76.20 & 2.17 & -1.69 \\
\hline 127.30 & 75.73 & 1.81 & -1.85 & 134.00 & 75.95 & 2.15 & -1.85 & 141.30 & 76.20 & 2.11 & -1.80 \\
\hline 128.12 & 75.76 & 1.86 & -1.78 & 134.00 & 75.96 & 2.16 & -1.49 & 141.40 & 76.20 & 2.15 & -1.84 \\
\hline 128.15 & 75.76 & 1.89 & -1.89 & 134.10 & 75.96 & 2.09 & -1.90 & 141.50 & 76.21 & 2.08 & -2.38 \\
\hline 128.20 & 75.76 & 1.84 & -1.74 & 135.53 & 76.01 & 1.97 & -2.06 & 141.60 & 76.21 & 2.07 & -2.30 \\
\hline 128.30 & 75.77 & 2.01 & -1.87 & 135.60 & 76.01 & 2.10 & -1.87 & 141.70 & 76.22 & 2.15 & -1.81 \\
\hline 128.60 & 75.78 & 1.90 & -1.61 & 135.60 & 76.01 & 2.00 & -1.91 & 141.80 & 76.22 & 2.07 & -1.82 \\
\hline 128.70 & 75.78 & 1.89 & -1.77 & 135.70 & 76.01 & 2.03 & -1.88 & 141.90 & 76.22 & 2.12 & -1.58 \\
\hline 128.80 & 75.78 & 1.84 & -1.69 & 135.80 & 76.01 & 2.06 & -1.78 & 142.00 & 76.23 & 2.08 & -1.80 \\
\hline 128.90 & 75.79 & 1.86 & -2.04 & 135.90 & 76.02 & 2.13 & -1.24 & 142.10 & 76.23 & 2.11 & -1.67 \\
\hline 129.00 & 75.79 & 1.86 & -1.78 & 136.00 & 76.02 & 2.05 & -1.82 & 142.20 & 76.23 & 2.12 & -1.76 \\
\hline 129.10 & 75.79 & 1.87 & -1.76 & 136.10 & 76.02 & 2.06 & -1.67 & 142.20 & 76.23 & 2.14 & -1.81 \\
\hline 129.12 & 75.79 & 1.88 & -1.90 & 136.20 & 76.03 & 1.99 & -1.85 & 142.30 & 76.24 & 2.12 & -1.83 \\
\hline 129.20 & 75.80 & 1.91 & -1.79 & 136.30 & 76.03 & 2.02 & -1.75 & 142.40 & 76.24 & 2.09 & -1.88 \\
\hline 129.30 & 75.80 & 1.87 & -1.75 & 136.40 & 76.03 & 2.04 & -1.96 & 142.50 & 76.25 & 2.15 & -1.76 \\
\hline 129.40 & 75.80 & 1.94 & -1.66 & 136.50 & 76.04 & 1.96 & -1.70 & 142.60 & 76.25 & 2.14 & -1.90 \\
\hline
\end{tabular}




\begin{tabular}{|c|c|c|c|c|c|c|c|c|c|c|c|}
\hline $\begin{array}{l}\text { Depth } \\
(\mathrm{m})\end{array}$ & $\begin{array}{l}\text { Age } \\
(\mathrm{Ma})\end{array}$ & $\delta^{13} \mathrm{C}$ & $\delta^{18} \mathrm{O}$ & $\begin{array}{l}\text { Depth } \\
(\mathrm{m})\end{array}$ & $\begin{array}{l}\text { Age } \\
(\mathrm{Ma})\end{array}$ & $\delta^{13} \mathrm{C}$ & $\delta^{18} \mathrm{O}$ & $\begin{array}{l}\text { Depth } \\
(\mathrm{m})\end{array}$ & $\begin{array}{l}\text { Age } \\
(\mathrm{Ma})\end{array}$ & $\delta^{13} \mathrm{C}$ & $\delta^{18} \mathrm{O}$ \\
\hline 142.70 & 76.25 & 2.17 & -2.05 & 148.90 & 76.48 & 2.11 & -1.65 & 194.25 & 78.31 & 2.38 & -2.09 \\
\hline 142.80 & 76.26 & 2.16 & -1.98 & 149.00 & 76.49 & 2.11 & -1.85 & 195.05 & 78.34 & 2.43 & -2.03 \\
\hline 142.90 & 76.26 & 2.18 & -1.97 & 149.10 & 76.49 & 2.18 & -1.63 & 199.06 & 78.49 & 2.55 & -1.89 \\
\hline 143.00 & 76.26 & 2.19 & -2.14 & 149.20 & 76.49 & 2.18 & -1.82 & 199.99 & 78.53 & 2.55 & -2.06 \\
\hline 143.10 & 76.27 & 2.18 & -1.77 & 149.30 & 76.50 & 2.13 & -1.86 & 201.29 & 78.58 & 2.54 & -2.07 \\
\hline 143.17 & 76.27 & 2.14 & -1.73 & 149.40 & 76.50 & 2.13 & -1.88 & 202.14 & 78.61 & 2.45 & -1.99 \\
\hline 143.20 & 76.27 & 2.10 & -2.18 & 149.40 & 76.50 & 2.17 & -1.76 & 204.76 & 78.71 & 2.55 & -2.03 \\
\hline 143.30 & 76.28 & 2.26 & -1.73 & 149.50 & 76.50 & 2.15 & -1.71 & 205.32 & 78.73 & 2.56 & -2.00 \\
\hline 143.30 & 76.28 & 2.16 & -1.99 & 149.60 & 76.51 & 2.22 & -1.81 & 206.51 & 78.77 & 2.48 & -1.87 \\
\hline 143.40 & 76.28 & 2.20 & -2.04 & 149.70 & 76.51 & 2.16 & -1.87 & 207.36 & 78.81 & 2.50 & -2.12 \\
\hline 143.50 & 76.28 & 2.18 & -2.01 & 149.80 & 76.52 & 2.20 & -2.13 & 208.24 & 78.84 & 2.55 & -1.99 \\
\hline 143.60 & 76.29 & 2.18 & -2.15 & 149.90 & 76.52 & 2.21 & -2.06 & 209.07 & 78.87 & 2.54 & -2.05 \\
\hline 143.70 & 76.29 & 2.21 & -2.05 & 150.00 & 76.52 & 2.21 & -1.92 & 209.19 & 78.88 & 2.52 & -2.21 \\
\hline 143.80 & 76.29 & 2.19 & -1.97 & 150.10 & 76.53 & 2.14 & -2.10 & 211.00 & 78.94 & 2.42 & -2.21 \\
\hline 143.90 & 76.30 & 2.17 & -1.90 & 150.10 & 76.53 & 2.15 & -1.84 & 212.24 & 78.99 & 2.19 & -1.99 \\
\hline 144.00 & 76.30 & 2.18 & -2.40 & 150.20 & 76.53 & 2.13 & -1.92 & 213.20 & 79.04 & 2.40 & -2.10 \\
\hline 144.10 & 76.30 & 2.15 & -1.90 & 150.30 & 76.53 & 2.19 & -1.85 & 214.00 & 79.07 & 2.33 & -2.10 \\
\hline 144.10 & 76.30 & 2.16 & -2.31 & 150.40 & 76.54 & 2.21 & -1.81 & 215.14 & 79.13 & 2.46 & -2.11 \\
\hline 144.20 & 76.31 & 2.26 & -2.06 & 150.50 & 76.54 & 2.22 & -1.94 & 215.97 & 79.17 & 2.47 & n.a. \\
\hline 144.30 & 76.31 & 2.27 & -2.18 & 152.00 & 76.60 & 2.19 & -1.87 & 217.25 & 79.23 & 2.42 & -2.12 \\
\hline 144.40 & 76.32 & 2.17 & -2.24 & 152.05 & 76.60 & 2.22 & -2.03 & 218.14 & 79.27 & 2.33 & -2.09 \\
\hline 144.50 & 76.32 & 2.17 & -1.89 & 152.10 & 76.60 & 2.18 & -1.71 & 219.23 & 79.32 & 2.53 & -2.09 \\
\hline 144.60 & 76.32 & 2.16 & -1.96 & 152.20 & 76.60 & 2.13 & -1.87 & 220.05 & 79.36 & 2.38 & -2.45 \\
\hline 144.70 & 76.33 & 2.16 & -1.94 & 152.30 & 76.61 & 2.09 & -2.07 & 221.10 & 79.41 & 2.52 & -2.14 \\
\hline 144.80 & 76.33 & 2.23 & -1.89 & 156.37 & 76.76 & 2.18 & -1.87 & 222.05 & 79.45 & 2.61 & -2.25 \\
\hline 144.90 & 76.33 & 2.17 & -1.93 & 157.13 & 76.79 & 2.13 & -2.00 & 223.00 & 79.50 & 2.35 & -2.31 \\
\hline 145.00 & 76.34 & 2.19 & -2.04 & 159.15 & 76.86 & 2.20 & -2.08 & 225.15 & 79.60 & 2.48 & -2.23 \\
\hline 145.10 & 76.34 & 2.14 & -2.11 & 160.16 & 76.90 & 2.08 & -1.91 & 226.10 & 79.64 & 2.48 & -2.23 \\
\hline 145.18 & 76.34 & 2.24 & -2.07 & 161.00 & 76.93 & 2.24 & -2.05 & 227.10 & 79.69 & 2.46 & -2.09 \\
\hline 145.20 & 76.35 & 2.18 & -2.28 & 162.33 & 76.98 & 2.25 & -1.88 & 228.06 & 79.74 & 2.37 & -2.14 \\
\hline 145.30 & 76.35 & 2.18 & -2.20 & 163.68 & 77.03 & 2.24 & -2.12 & 229.06 & 79.78 & 2.47 & -2.28 \\
\hline 145.40 & 76.35 & 2.19 & -2.15 & 164.05 & 77.04 & 2.27 & -1.93 & 230.00 & 79.83 & 2.45 & -2.44 \\
\hline 145.50 & 76.36 & 2.18 & -2.10 & 165.06 & 77.08 & 2.30 & -2.02 & 231.02 & 79.88 & 2.39 & -2.24 \\
\hline 145.60 & 76.36 & 2.13 & -1.89 & 166.05 & 77.12 & 2.33 & -2.05 & 232.05 & 79.93 & 2.43 & -1.89 \\
\hline 145.70 & 76.36 & 2.16 & -1.55 & 167.30 & 77.16 & 2.31 & -2.15 & 233.25 & 79.98 & 2.37 & -2.20 \\
\hline 145.80 & 76.37 & 2.10 & -1.93 & 168.00 & 77.19 & 2.29 & -2.10 & 234.01 & 80.02 & 2.45 & -2.12 \\
\hline 145.90 & 76.37 & 2.13 & -1.93 & 169.29 & 77.24 & 2.30 & -1.93 & 235.55 & 80.09 & 2.38 & -2.22 \\
\hline 146.00 & 76.37 & 2.10 & -1.97 & 170.15 & 77.27 & 2.28 & -2.02 & 236.53 & 80.14 & 2.30 & -2.26 \\
\hline 146.10 & 76.38 & 2.08 & -1.93 & 171.05 & 77.30 & 2.27 & -2.08 & 237.12 & 80.16 & 2.30 & -2.23 \\
\hline 146.10 & 76.38 & 2.16 & -1.98 & 172.15 & 77.34 & 2.30 & -1.92 & 238.05 & 80.21 & 2.35 & -2.38 \\
\hline 146.20 & 76.38 & 2.15 & -1.94 & 173.05 & 77.38 & 2.42 & -1.90 & 239.21 & 80.26 & 2.35 & -2.32 \\
\hline 146.30 & 76.39 & 2.18 & -1.83 & 174.06 & 77.42 & 2.26 & -1.84 & 240.14 & 80.31 & 2.51 & -2.24 \\
\hline 146.40 & 76.39 & 2.18 & -2.08 & 175.00 & 77.46 & 2.23 & -1.98 & 241.00 & 80.35 & 2.67 & -2.18 \\
\hline 146.50 & 76.39 & 2.26 & -1.77 & 176.21 & 77.51 & 2.26 & -1.94 & 242.14 & 80.40 & 2.46 & -2.24 \\
\hline 146.60 & 76.40 & 2.20 & -2.16 & 178.69 & 77.62 & 2.25 & -1.96 & 243.16 & 80.45 & 2.40 & -2.34 \\
\hline 146.70 & 76.40 & 2.21 & -2.07 & 179.10 & 77.64 & 2.20 & -2.23 & 244.00 & 80.49 & 2.41 & -2.37 \\
\hline 146.80 & 76.40 & 2.19 & -2.02 & 180.10 & 77.69 & 2.27 & -2.12 & 245.06 & 80.54 & 2.47 & -2.29 \\
\hline 146.90 & 76.41 & 2.26 & -2.14 & 181.80 & 77.76 & 2.33 & -2.15 & 246.18 & 80.59 & 2.40 & -2.22 \\
\hline 147.00 & 76.41 & 2.18 & -2.44 & 182.20 & 77.78 & 2.34 & -2.20 & 247.10 & 80.64 & 2.22 & -2.17 \\
\hline 147.10 & 76.42 & 2.18 & -1.97 & 183.07 & 77.82 & 2.31 & -2.41 & 248.15 & 80.69 & 2.41 & -2.12 \\
\hline 147.12 & 76.42 & 2.28 & -1.86 & 184.17 & 77.87 & 2.40 & -2.29 & 249.10 & 80.73 & 2.44 & -2.41 \\
\hline 147.20 & 76.42 & 2.27 & -1.81 & 184.92 & 77.90 & 2.24 & -1.82 & 250.16 & 80.78 & 2.45 & -2.23 \\
\hline 147.30 & 76.42 & 2.18 & -1.97 & 186.48 & 77.97 & 2.27 & -1.96 & 251.19 & 80.83 & 2.46 & -2.28 \\
\hline 147.40 & 76.43 & 2.21 & -1.84 & 187.18 & 78.00 & 2.40 & -2.05 & 252.20 & 80.88 & 2.48 & -2.44 \\
\hline 147.50 & 76.43 & 2.19 & -1.90 & 188.28 & 78.05 & 2.44 & -1.92 & 253.00 & 80.91 & 2.58 & -2.23 \\
\hline 147.60 & 76.43 & 2.19 & -1.68 & 189.10 & 78.09 & 2.44 & -2.14 & 254.09 & 80.97 & 2.41 & -2.25 \\
\hline 147.70 & 76.44 & 2.21 & -1.79 & 190.08 & 78.13 & 2.40 & -1.91 & 255.12 & 81.01 & 2.48 & -2.35 \\
\hline 148.70 & 76.47 & 2.07 & -1.72 & 191.30 & 78.18 & 2.69 & -1.55 & 256.17 & 81.06 & 2.56 & -2.62 \\
\hline 148.75 & 76.48 & 2.19 & -1.85 & 192.00 & 78.22 & 2.50 & -1.89 & 257.08 & 81.11 & 2.36 & -2.30 \\
\hline 148.80 & 76.48 & 2.11 & -1.67 & 193.42 & 78.28 & 2.45 & -2.27 & 258.18 & 81.16 & 2.11 & -2.47 \\
\hline
\end{tabular}




\begin{tabular}{llll}
\hline $\begin{array}{l}\text { Depth } \\
(\mathrm{m})\end{array}$ & $\begin{array}{l}\text { Age } \\
(\mathrm{Ma})\end{array}$ & $\delta^{13} \mathrm{C}$ & $\delta^{18} \mathrm{O}$ \\
\hline 259.10 & 81.20 & 2.45 & -2.29 \\
260.03 & 81.25 & 2.47 & -2.23 \\
261.00 & 81.29 & 2.44 & -2.25 \\
262.11 & 81.34 & 2.41 & -2.24 \\
263.06 & 81.39 & 2.40 & -2.48 \\
264.17 & 81.44 & 2.35 & -2.38 \\
265.20 & 81.49 & 2.45 & -2.40 \\
266.24 & 81.54 & 2.42 & -2.92 \\
267.00 & 81.57 & 2.47 & -2.46 \\
268.02 & 81.62 & 2.41 & -2.47 \\
269.19 & 81.68 & 2.42 & -2.55 \\
270.25 & 81.73 & 2.28 & -2.38 \\
271.14 & 81.77 & 2.48 & -2.59 \\
272.11 & 81.82 & 2.44 & -2.62 \\
273.17 & 81.87 & 2.47 & -2.65 \\
274.00 & 81.91 & 2.51 & -2.44 \\
275.13 & 81.96 & 2.77 & -2.54 \\
276.04 & 82.00 & 2.51 & -1.76 \\
277.05 & 82.05 & 2.45 & -2.24 \\
278.10 & 82.10 & 2.37 & -1.70 \\
279.25 & 82.15 & 2.55 & -2.36 \\
280.11 & 82.19 & 2.42 & -2.19 \\
\hline
\end{tabular}

\begin{tabular}{llll}
\hline $\begin{array}{l}\text { Depth } \\
(\mathrm{m})\end{array}$ & $\begin{array}{l}\text { Age } \\
(\mathrm{Ma})\end{array}$ & $\delta^{13} \mathrm{C}$ & $\delta^{18} \mathrm{O}$ \\
\hline 281.10 & 82.24 & 2.44 & -2.28 \\
282.10 & 82.29 & 2.60 & -2.44 \\
283.17 & 82.34 & 2.33 & -2.01 \\
284.05 & 82.38 & 2.50 & -2.33 \\
284.96 & 82.42 & 2.58 & -2.40 \\
286.04 & 82.47 & 2.54 & -2.39 \\
287.18 & 82.53 & 2.54 & -2.48 \\
288.14 & 82.57 & 2.54 & -2.34 \\
289.00 & 82.61 & 2.50 & -2.39 \\
290.10 & 82.67 & 2.67 & -2.31 \\
291.09 & 82.71 & 2.63 & -2.23 \\
292.02 & 82.76 & 2.63 & -2.58 \\
293.03 & 82.80 & 2.67 & -2.38 \\
294.01 & 82.85 & 2.52 & -2.30 \\
295.06 & 82.90 & 2.66 & -2.48 \\
296.07 & 82.95 & 2.65 & -2.29 \\
297.16 & 83.00 & 2.73 & -2.37 \\
298.12 & 83.04 & 2.66 & -2.33 \\
299.01 & 83.09 & 2.63 & -2.46 \\
300.13 & 83.14 & 2.77 & -2.40 \\
301.21 & 83.18 & 2.70 & -2.28 \\
302.12 & 83.23 & 2.86 & -2.41 \\
\hline
\end{tabular}

\begin{tabular}{|c|c|c|c|}
\hline $\begin{array}{l}\text { Depth } \\
\text { (m) }\end{array}$ & $\begin{array}{l}\text { Age } \\
(\mathrm{Ma})\end{array}$ & $\delta^{13} \mathrm{C}$ & $\delta^{18} \mathrm{O}$ \\
\hline 303.35 & 83.29 & 2.76 & -2.57 \\
\hline 304.10 & 83.33 & 2.73 & -2.37 \\
\hline 305.00 & 83.37 & 2.73 & -2.53 \\
\hline 306.05 & 83.42 & 2.82 & -2.45 \\
\hline 307.01 & 83.46 & 2.85 & -2.11 \\
\hline 307.90 & 83.51 & 2.68 & -2.29 \\
\hline 308.00 & 83.51 & 2.70 & -2.37 \\
\hline 309.00 & 83.56 & 2.74 & -2.34 \\
\hline 309.90 & 83.60 & 2.77 & -2.69 \\
\hline 310.11 & 83.61 & 2.70 & -2.52 \\
\hline 311.28 & 83.67 & 2.63 & -2.41 \\
\hline 311.90 & 83.69 & 2.52 & -2.58 \\
\hline 314.90 & 83.84 & 2.46 & -2.63 \\
\hline 317.90 & 83.98 & 2.49 & -2.64 \\
\hline 319.90 & 84.07 & 2.43 & -2.54 \\
\hline 321.90 & 84.17 & 2.62 & -2.50 \\
\hline 2.74 & $\begin{array}{l}\text { Data of } \\
\text { Jynkyns } \\
\text { et al. (1994) } \\
\text { and Jarvis } \\
\text { et al. (2002) }\end{array}$ & & \\
\hline 2.18 & new data & & \\
\hline
\end{tabular}

Supplementary Table 3 Age and depth of biostratigraphic and carbon-isotope events used to construct a revised age-model for the Shuqualak-Evans core.

\begin{tabular}{llll}
\hline Age Model & Tie points & Age (Ma) & Source \\
\hline Function 1 & 1: base Micula prinsii $(12.80 \mathrm{~m})$ & 67.30 & Gradstein et al. 2012 \\
$(9.45-16.76 \mathrm{~m})$ & 2: base Lithraphidites quadratus $(16.76 \mathrm{~m})$ & 69.18 & Gradstein et al. 2012 \\
Function 2 & 1: base Lithraphidites quadratus $(16.76 \mathrm{~m})$ & 69,18 & Gradstein et al. 2012 \\
$(16.76-27.43 \mathrm{~m})$ & 2: top Reinhardtites levis $(21.34 \mathrm{~m})$ & 70.14 & Gradstein et al. 2012 \\
Function 3 & 1: base CMBE $(46.94 \mathrm{~m})$ & 73.00 & Voigt et al. 2012 \\
$(28.96-82.30 \mathrm{~m})$ & 2: top Radotruncana calcarata $(82.30 \mathrm{~m})$ & 75.71 & Gradstein et al. 2012 \\
Function 4 & 1: base Uniplanarius sissinghii $(134.11 \mathrm{~m})$ & 77.61 & Gradstein et al. 2012 \\
$(83.82-249.94 \mathrm{~m})$ & 2: base Broinsonia parca constricta $(239.27 \mathrm{~m})$ & 81.38 & Gradstein et al. 2012 \\
Function 5 & 1: presence of Arkhangelskiella cymbiformis $(251.97 \mathrm{~m})$ & 83.20 & Gradstein et al. 2012 \\
$(251.46-253.19 \mathrm{~m})$ & 2: presence of Dicarinella asymetrica $(253.19 \mathrm{~m})$ & 83.64 & Gradstein et al. 2012 \\
\hline
\end{tabular}

